\title{
THE COMPARATIVE COSTS OF LOCATION OF MANUFACTURING FIRMS IN URBAN AREAS: A BOSTON CASE ST UDY
}

\author{
Andrew N. Hamer*
}

Georgia State University

\section{PART I. INDUSTRIAL LOCATION BEHAVIOR IN AN URBAN CONTEXT}

\section{INTRODUCTION}

This paper develops a framework for analyzing the relevant costs of locating manufacturing firms at different sites in an urbanarea, through a case study of Boston, Massachusetts. An attempt is made to understand what specific inputs affect the variation in the costs of productionover space. Furthermore, with the use of model firms from various industries, an attempt is made to rank these inputs in order of importance.

\section{DECLINES IN MANUFACTURINGEMPLOYMENT IN U.S. CENTRAL CITIES}

The concern over trends in manufacturing employment in urban areas the last few years requires little explanation. Manufacturing remains a key sector for both central cities and their suburbs. This is the case not only because of the size of that sector, but also because of its effects on the growth of the ancillary employment that services manufacturing firms and its employee-consumers. Therefore, the prospects for central city and suburban development depend to an important extent on the future levels of manufacturing jobs.

There is little controversy concerning the direction of manufacturing employment trends within urban areas. Standard reviews of the data can be sought in the works of Kain, Birch, and Ganz. ${ }^{1}$ Their findings not only reveal a dichotomy between center city and suburb but also between different sets of SMSAs, ranked by such criteria as population growth, region of origin, and total populations. These various rankings are, of course, only suggestive of the factors behind the decline of manufacturing employment in major central cities. They reflect long-term shifts in high regionalgrowth patterns away from the Northeast and toward the West and South. Implicit in the rankings are a number of very general reasons which, in addition, help explain why declining central cities coexist with growing suburban rings. Among the factors cited are the high cost of land in the central city, together with the unavailability of suitable sites, the high costs of government services, and high labor costs. These factors are presented without a framework which would allow the reader to determine which reasons are important and to what degree they affect industrial behavior. The only theme connecting the se various explanations is the assumption that cost differentials among locations motivate manufacturing firms making location decisions.

* This paper was prepared with funds from the Department of Economic Research of the Economic Development Administration in the Department of Commerce, project number OER-015-G-70-4, under the direction of John Kain, Harvard. 


\section{THE BOSTON EXPERIENCE}

To analyze and quantify the alternate costs of location for manufacturing firms within urban areas, a decision was made to study information gathered in Boston. Boston serves as an illustration of the mature industrial urban area, where the process of central city decline can be viewed quite clearly. Manufacturing employment in the city fell from 101, 000 in 1950 to 87,000 in 1960 , and 65,000 in $1970 .^{2}$ This decline has affected virtually all manufacturing categories. During that period, manufacturing dropped from the largest to the fourth sector in the city, even though total employment remaining relatively stable, totaling 498, 000 in 1950,480, 000 in 1960, and 516, 000 in 1970. In fact, the one optimistic note in Boston's employment situation was the growth in finance, insurance, real estate, services, and government. These three sectors showed an average growth of 4,200 jobs a year during 1950-1970 and totalled 276,000 jobs at the end of the period.

In Boston's suburbs, manufacturing remained the key sector. Between 1950 and 1968, manufacturing jobs rose at a rate of roughly 2,700 per year from an initial base of 179,000 . With few exceptions, all sectors of this suburban economy registered healthy increases during the period, paced by a yearly increase of 7,900 jobs in the service sector.

\section{MOBILITY OF BOSTON AREA MANUFACTURING FIRMS AND LOCATION CONSIDERATIONS}

To gain a better understanding of the causes of the markedly different performance of central cities relative to their suburbs in manufacturing employment, it would be useful to have information on the motivations of new and established firms inmaking location decisions. Such a survey would, in effect, provide hypotheses and a check on the analysis of relevant urban location costs presented in subsequent chapters. Fortunately, a recent survey of this kind is available for the Boston Area. In late 1969, the Boston Economic Development and Industrial Commission (E.D.I. C.) surveyed firms both within Boston and in the rest of the SMSA. ${ }^{3}$ In personal interviews, a series of questions were asked concerning firm history, employment, plant characteristics, marketing behavior, and location variables deemed important. "The survey excluded all manufacturing firms with fewer than 20 employees. Remaining firms in each area were classified into a matrix containing employment size categories as one dimension (row) and Standard Industrial Classification categories as the other (column). In any one column, the number of firms surveyed depended on the number of firms contained in the given industry relative to the total number; an industry with a relatively large number of establishments would be more heavily sampled than an industry with a relatively smaller number of establishments. The number of firms sampled within any given cell of the same column was a function of the employment size class (row). The larger the employment sizeclass, the larger the percentage of firms in the cell that were sampled. Fifty-three percent of the relevant core city universe and 16 percent of the relevant suburban ring universe was sampled by personal interviews with corporate officials.

The results of the survey are illuminating. Suburban firms with previous locations appear to be highly mobile, with nearly one-half moving to new sites since 1960. By contrast, the corresponding central city firms appear to be substantially less mobile, with nearly half of the sampled firms moving to 
present sites prior to 1940 and only 7 percent making moves after 1960 . When the question of possible moves in the (indeterminate) future was posed to all sampled firms, however, the results weremarkedly different. Forty-two percent of the sampled core firms and 29 percent of the sampled suburban firms reported they were considering a shift in location. Significantly, nearly eight-tenths of Boston sampledfirms contemplating a new site we re seriously considering locations outside the city, while only 3 percent of suburban firms with plans to move were considering central city sites.

Among reasons for considering moves, plant space-related factors dominated the responses of sampled firms in both areas, accounting for roughly 40 percent of the answers in each case. Labor-related factors were also important in both cases, accounting for about one-third of core responses and one-fifth of suburban responses. Space-related reasons were generally given higher urgency rating ${ }^{4}$ than labor-related reasons, with the only noticeable exception being "availability of skilled labor, "a category whose urgency rating and percentage of responses was quite similar for both core and suburban firms. The common preoccupation with labor-related problems appears to reflect the dissatisfaction with tight labor markets prevalent across the nation until 1970. One noticeable omission from the list of factors listed is the local taxissue. Unfortunately verylittle can be concluded about this, since the survey format required those interviewed to volunteer that particular item after first evaluating and ranking a list of othe $\bar{r}$ factors specifically submitted by the interviewer.

Firms not interested in moving gene rally mirror a concern for the same items as those interested in moving. Two noticeable trends emerge. First, the cost of different labor grades appears to be a low priority item among reasons for staying put in both areas. Second, within the central city, the categories "large outlay to move" and "desire to be close to existing clients" appear to be very important; these two areas account for 25 percent of responses and constitute palpable evidence of the role played by inertia among existing firms when the advantages of central city and suburban sites are juxtaposed.

Additional questions provided suggestive evidence that transportationrelated factors are not significant new location determinants, i.e., that accessibility to markets andaccessibility to suppliers are secondary factors in the location decision. Sixty percent of the core's supply points and 73 percent of suburban supply points a re non-SMSA in origin, fully half of the se non-SMSA points in each category being outside New England. Similarly the allocation of total sales allocated by market areas for sampled firms shows that Boston firms sell 70 percent of their output to non-SMSA sources while the comparable datum for suburban firms is 90 percent; only a small portion of these exports are to New England points. Finally both groups of firms rely heavily ontrucking and highways for freight movement, suggesting reliance on a highly ubiquitious transportation system where, ideally, each firm is its own terminal. Given the evidence on the location of supply points and sales points, the limited access highwaymileage differential of any two points within the Boston area (including the non-metropolitan periphery) appears small and therefore not very decisive. This implies nothing about the advantages of micro-accessibility; it is consistent with actions of firms that may bid higher for land near limited access highways than for land removed from the same.

The Boston survey suggests a number of fruitful leads in an attempt to explore the decline of the centralcity. It is useful, next, to develop a frame work which will allow for the quantification of the core's disadvantage versus the outlaying areas. 


\section{PART II: A TENTATIVE FRAMEWORK FOR INTRA- METROPOLITAN LOCATION}

\section{INTRODUCTION}

Most studies of industrial locations assume that the individual firm chooses that location for its operations which maximizes its profits. Technology is specified and the various revenue and cost components a re given spatial subscripts such that $I_{j}=R_{j}-C_{j}$, where $I_{j}$ represents profits of operations at potential plant site $j$, while $R_{j}$ and $C_{j}$ represent total revenues and total costs of operations at that location. Further, $R_{j}=P_{j} \cdot Q_{j}$, where $P_{j}$ represents the factory price of output and $Q_{j}$ equals the quantity sold at price $P_{j}$ aggregated over all market points $i \quad(\Sigma q i=Q j)$. Finally, $C_{j}=c_{j} Q_{j}, \cdot$ where $c j$
is equal to costs per unit of output.

Theories of location can be classified by their approach to the revenue function and the costfunction. In investigating the revenue function, the analyst must arrive at a definition of each total receipts profile with respect to output, corresponding to each potential plant location site, j. Following that, the basicissue to be broached is whether the aggregated total receipts profile for the firm shifts with respect to output as alternate plant sites are considered or whether, if fact, that profile is invariant to changes in $j$. The resolution of this question is important because, if the total revenue profile with respect to output is site-invariant, the profit maximization becomes largely a matter of finding the site associated with the lowest costs of production for the relevant output range.

Implicit in any discussion of the behavior of the total costs profile with respect to output are certain assumptions about the production function. The firm is assumed to perform engineering studies associating all possible outputs with technically efficient combinations of inputs. The production function reveals the maximum output obtainable for every possible input combination, given existing techniques of production. In the generalized case of the single-valued continuous function, a continuum of production techniques is assumed such that, given a particular output target, the firm can move incrementally from production formats relying heavily on one input or sets of inputs to other formats that rely less heavily on these factors. Following well trodden theoretical ground, it can be shown that for any level of output, the particular input combinations chosen depend on the relative prices of the inputs, according to the principle that, whenever possible, relatively expensive inputs are replaced by relatively inexpensive substitutes.

If it is assumed that the firm is a price-taker in the input markets and that input prices are fixed at any one particular site, then the firm is faced with potential spatial variations in the relative prices of different inputs. The rational response of the firm, in the context of site-invariant total revenue lines with respect to output is to map out total cost curves at each site, and then, by inspection, determine simultaneously the lowest cost site and the cost-minimizing (profit maximizing) level of output. If the revenue lines are site-specific, then the process of inspection is slightly more complex and the chosen site may not coincide with the lowest costs for the optimal output target. The central issue of controversy associated with the cost function is, of course, whether the underlying technically feasible production processes may be so limited, even in the long-run, that, in the extreme, only one combination of inputs is provided for each level of output and no substitution is allowed. The total costs curves with respect to output then become site-specific and the process of inspection will againyield the profitmaximizing site, though optimal output levels will remain indeterminate. 
This problem is not resolved by admitting a limited number of alternate production techniques, as Dorfman has demonstrated in a discussion that abstracts from location considerations. 5

\section{RECEIVED LOCATION THEORIES}

Various writers have attempted to move beyond this very general discussion to a statement of which variables should be stressed and which additional assumption should be made.

There are basically two schools of thought to contend with: regional and "urban". 6 Regional theories have been explored quite thoroughly and, for the purposes of this paper, they can besummarily (and unjustly) dismissed by noting that they fail to deal explicitly with the competition for the use of space. Urban location models, dating back to work of Thünen and other students of agricultural rent gradients, can be profitably classified into two groups, following Alonso's suggestion. 7

One formulation involves solving the firm's location problem in te rms of a generalizedbid-price analysis. Bid-price curves represent a schedule of hypothetical land rents such that the particular firm is indifferent among alternate locations. Each site, after inclusion of the hypothetical land rent corresponding to a given bid curve, yields equal profits for that firm. Each firm has a family of such bidcurves, each representing a different profit level, with profit levels being inversely related to the hierarchy of curves. Alonso has suggested thatgiven the surface of actual land prices in an urban area, and given the firm's family of bid-pricecurves, then the optimal location corresponds graphically to the point where the lowest bid-pricesurfaces are tangent to the actual surface of land prices. If the bid curves are constructed with full allowance for input price variations, potential input substitution, potential economies of scale, and potential variation in revenues, this process corresponds to the generalized profit maximizing location models.

Variants of this approach have served as the point of departure for several studies. ${ }^{8}$ The focus of this literature is on hypothetical aggregate land use patterns and not on the individual firm's explicit production decisions. This approach has yielded a framework for making observations concerning historical changes in urban land uses popularly associated with the last 60 years in the United States.

An alternate synthesis of generallocation andland rent theory, suggested by Alonso, has not been explored sufficiently. Without great elaboration, Alonso has suggested that the theory of optimal location for the profit maximizing firm consider land inputs and their prices explicitly along withother inputs. That is the approach adopted for this paper.

\section{AN OPERATIONAL MODEL OF INTRA-METROPOLITAN LOCATION}

To make the analysis tractable, two important simplifying assumptions are made to convert the problem from one of profit-maximization to one of cost-minimization. First, it is assumed that the market facing a firm at alternate sites is unaffected by location ch ices of other firms. While this assumption necessarily reduces the generality of the analysis, it greatly simplifies the problems of empirical research. Second, it is assumed that the increasing reliance by firms on ubiquitous highway systems makes distribution costs (and therefore deliveredprice) differentials negligible within given urban area. That is, at different sites within that area, the delivered price of the final good to customers within that area would be roughly equivalent to 
the factory price. Finally, the evidence presented in Part I on the location of sales and supply points for firms surveyed by the E.D.I. C. suggests that, on average, large markets exist for the urban firms products at points which are distant relative to any intra-urban differences measured in highway miles. This is tantamount to saying that delivery costs for non-area markets will not be significantly affected if a firm contemplates hypothetical moves from one site A to another site B, 10 to 15 miles away in a given direction. Thus variations in total revenues as a function of output are assumed to be slight at alternate urbanarea sites, i. e. total revenues a re site-invariant. Naturally these assumptions will be more readily applicable to some industries than others.

Even with this assumption, it nevertheless remains true that the determination of the least cost location requires a simultaneous determination of the level of output. Once again, for the purpose of this analysis, the allowable output ranges were restricted by considering only the behavior of firms in particular employment size classes (between 100 and 500 employees). It was also assumed that the site-specific cost curves over the relevant output ranges could themselves be grouped by area (i.e. groups of adjacent sites in the central business district, the outer suburbs, the inner suburbs, ect.). The formal solution could then be accomplished by inspection, determining the lowest area-specific cost curves for the relevant size firms.

The basis for cost minimization rests on the possibilities for physical input substitution and on the spatial variations in the price of inputs which can, if fact, trigger potential substitutions. For simplicity, this type of analysis was undertaken within a model that takes the location and price of all inputs as given.

The chief operative construct in the analysis was the creation of hypothetical firms in several industries assumed capable of evaluating alternate location sites within the Boston area. In particular, firms were as sumed to consider locating in industrially zoned sites in the city of Boston and in areas along two suburban circumferential highways. Evidence gathered to describe these hypothetical firms was restricted to plants employing between 100 and 500 workers. The particularindustries chosen were as sumed to be illustrative of those whose investments in machinery and equipment per worker were neither relatively low (as in apparel products) nor relatively high (petrochemicals, aircraft parts); whose average yearly payroll per employee was reletively high; and whose growth potential was good. 9 In this way focus was placed on the type of firms most likely to attract the attention of public officials concerned with intra-urban mobility. The firm was assumed to evaluate each site by trading off certain discrete "blocks" of cost minimizing features against one another. As an illustration, elaborated below, variations in building space rental costs over space could be compared with variations in labor costs over space. For any given set of inputs, movement over space which resulted in a variation in costs would be reflected by a change in net operating profits (before state and federal taxes). Prior to this, it would be necessary for the hypothetical firm to determine what inputvariations were possible along a given isoquant and what variations in relative prices existed over space.

To summarize, this model assumes that the firm's profits are site $j$

$$
\mathrm{II}_{\mathrm{j}}=\mathrm{R}_{\mathrm{j}}-\mathrm{C}_{\mathrm{j}}
$$

where $R_{j}$, total revenues at location $j$, is invariant to $j$ within the urban area. $C_{j}$, total cost of operations at location $j$, is assumed to varyfrom site to site as a result in unit costs, $c_{j}$. Over the range of output being considered (for firms with 100 to 500 employees), no economies of scale are allowed;i. e. $c_{j}$ 
is the same for the output of 100 employees in a firm as for 500 employees. Now, per unit costs,

$$
c_{j}=p_{j}^{1} L_{j}+p_{j}^{s} S_{j}+p_{j}^{w} W_{j}+p_{j}^{g} G_{j}+p_{j}^{m} M_{j}+p_{j}^{b} B_{j}+p_{j}^{i} I_{j}+p_{j}^{t} T_{j}
$$

where L=land, S=structures, W=skilled labor, U=unskilled labor, G=government services, $M=$ raw materials, $B=$ business services, $I=i n t e r m e d i a t e ~ g o-$ ods, $\mathrm{T}=$ transportation costs.

Of the above cost components, $\mathrm{p}_{j}^{\mathrm{m}} \mathrm{M}_{j} ; \mathrm{p}_{\mathrm{j}}^{\mathrm{b}} \mathrm{B}_{j} ; \mathrm{p}_{j_{j}}^{\mathrm{I}_{\mathrm{j}}}$; and $\mathrm{p}_{\mathrm{j}}^{\mathrm{t}} \mathrm{Tj}$ a re all assumed invariant with location in the urban area. That is, the quantities of materials, intermediate goods, business services, and transportation inputs are assumed not to vary in any systematic ways as different locations a re cosidered both because their usage does not change as different land-structure combinations are considered, and because, as seen below, the potential variation in labor intensity of operations can be minimized. One can go further and claim that spatial price variations for these other factors (materials, intermediate goods, business services, transportation inputs) are non-existent. Raw materials and intermediate goods shipped in from outside the urban area are not likely to vary incosts, on the average. The assumption derived from the Boston survey on the sources of inputs and the logic developed in discussions on market delivery costs both suggest that intra-metropolitan site variations have a miniscule impact on attempts to locate strategically with regard to input markets. Similarly, it appears reasonable to postulate that the recent period of decentralization has effectively eliminated the cost differentials in providing business services and intermediate goods supplied by urban area firms. In otherwords, the agglomerative economies associated with the nineteenth century core city are now being shared by a far larger zone, as the process of suburbanization yields a reas of relatively high density conductive to such positive externalities. Suburbanareas notonly possess the basic infrastructure (streets, water mains, sewerage facilities, electric power) but also a concentration of manufacturing firms which allows, to a large degree, a relatively costless interaction of firms with local intermediate requirements.

The first topic to be investigated in Part III is the spatial variations in land prices, $p_{j}^{1}$. Having established that $p_{j}^{1}$ varies significantly, it is necessary to detail the assumptions that must be made prior to considering the substitution of $\mathrm{S}_{\mathrm{j}}$ for $\mathrm{L}_{\mathrm{j}}$. It is assumed that industrialbuilding codes are uniform throughout the urban area and that the costs of building materials and other construction expenditures are the same throughout. Structure costs a re allowed to vary only as a result of specification(i. e. multi-level versus single story) and notover space. Theoretically, these structural differences need not reflect any accompanying diffe rentials in ope rational efficiency, being instead mechanical responses to varying underlying land costs. In studying the possibility of substitution $S_{j}$ for $L_{j}$ land and structure costs are annualized, and it is assumed that liquid capital can be treated, at least for the contemporary metropolitan area, as perfectly mobile, and its costs, as constant over space. This can be justified by reference to the absence of differential risk for central city banks in making commercial-industrial loans over space and by noting the rapid growth in the size of suburban banks. If suburban firms were, infact, discriminated against by being forced to pay a premium on loans from central city banks, this feature would most likely be peculiar to particular metropolitan a reas.

For the purposes of this study, it is assumed that the provision of government services to industry is relatively similar over a metropolitan area. Any cost differentials can be viewed as being caused by price differentials per unit of a uniform bundle of services. This price differential can be ex- 
plained by the municipal use of the property tax to finance these services. Firms areforced to pay for more than services rendered. Differential property tax rates for industry are thus accounted for largely by the central city's need to provide for poverty-linked services.

One feature of the property tax has implications for the study of land-structures substitution possibilities. The cost of government services

$$
P_{j}^{g} G_{j}={ }_{\Phi j}\left[p_{j}^{1} L_{j}+p_{j}^{s} S_{j}\right]
$$

where $\Phi$ is the property tax rate. That cost can be viewed as a yearly,"sales tax" on landand structures. On the one hand, this tax reinforces the variations in $\mathrm{p}_{j}^{1}$ through the introduction of a differential surcharge against central areas. At the same time, it raises questions about any impact on the substitution possibilities of multilevelfor single story structures in central cities.

One final area requires attention prior to a consideration of the possibilities of substitution between structures and land, and the question of spatial variation in building space costs. It is important to establish whether or not systematic variations in labor costs $\left(\mathrm{p}_{j}^{\mathrm{W}} \mathrm{W}_{j}+\mathrm{P}_{j} \mathrm{u}_{U_{j}}\right)$ might offset or reinforce the core's disadvantage with respect to space costs.

If, for the moment, variations in labor grades are ignored, then there are two ways through which cost reductions on the process of production can be achieved. Labor wage differentials may permit the firm, in making location decisions, to switch to a more labor-intensive form of operation. Alternatively, if machinery and equipment investment per job is given a constant over $j$, the labor needs may be met more cheaply at those sites where this undifferentiated "standard" labor is relatively cheap. This too will result in lower operating costs.

The analysis of these questions was again restricted to the hypothetical firms, none of which are associated traditionally either with low investments per worker or with the heavy utilization of low skill laborers. Evidence gathered from studies of the behavior of similar U.S. firms in making inter-regional and international location decisions suggests a number of reasons why fixed coefficient patterns appear rational. 10 For simplicity, the analysis can be restricted temporarily to potential substitutions involving only one labor grade, labelled "standard". Beyond relatively low output rates, capital intensive processes tend to have an advantage over labor intensive processes. The former generate increased production operating speeds which are sufficient to reduce labor time needs substantially, compared to those prevailing in the laborintensive case. The use of relatively capital intensive processes appears to lower costs over a wide range of labor to capital cost ratios. If analysis is extended to the costing of total plant operations rather than the performance of specifictasks, then attempts to maintainquality control and the pace of operations suggest large differentials in supervisorymanagement requirements between captial and labor intensive operations. These remarks apply with greater force if, instead of considering "standard" labor, the firm evaluates the possibility of utilizing one specific sub-group more intensively, namely, low-skilled labor. The potential marginal rate of substitution of "standard" labor for capital is, at best, large for the hypothetical firms discussed. With the utilization of low skill labor, these substitutions become far larger, reinforcing any tendency toward fixed coefficient behavior. ${ }^{11}$

For urban areas like Boston, this conclusion is especially suggestive for, in considering labor price variations over space, only low skill labor 
appears to show variations significant enough to trigger any potential input substitutions. This conclusion fits into a framework which hypothesizes that the dispersion of manufacturing jobs over the last few decades, accompanied by the increasing affluence (with its corresponding desire for larger bundles of residential services) and mobility of the labor force has redistributed the urban labor pool away from its core area concentration. This has contributed to a tendency toward wage equalization by skill level over space. This is consistent with the assertion that the central city has a concentration of rather unique low-skill, low-wage labor, as long as it can be established that this pool is of limited relevance to the average manufacturing location decision.

Few theoretical arguments exist in this area. Some suggest the existence of a money wage gradient in urban areas, such that labor in outlying areas can be hired for less than in the central city. Moses, ${ }^{12}$ for example, relies on a monocentric employment model in which suburban workers hold only dispersed local residence-serving jobs. If all employees, including local ones, share the same residential areas, it follows that they pay the same price per unit of housing at a given site. The Moses model postulates that central workers bid for identical bundles of residential services in such a way that the price of such housing is lower at less accessible points from the dominant a rea of employment than at closer points. Thus, for local equilibrium to prevail for suburban workers, money wages received at any site must decline with distance from the core; otherwise, suburban workers farther away from the core would be better off, experiencing lower prices for identical bundles of residential services than those working nearer to the core.

Such a wage gradient for local workers ignores the fact that substantial subcenters of employment do exist in our metropolitan areas. Thus, in fact, accessibility to suburban jobs has value and the argument based on a monocentric model is not realistic. As Muth has noted, ${ }^{13}$ in a multicenter model, residential land rentals and housing prices paid by workers employed at any given site decline in all directions to reflect declining net money incomes, after transportation expenditures. The land rent gradient from different work centers creates, in effect a series of residential subcenter catering predominantly to workers of their respective work subcenters. Boundaries are thus created a round each residential subcenter such that, at a boundary, housing prices are identical. At that point, boundary residents working at alternate work centers have equal money incomes net of transportation costs. Over time, as jobs shift awayfrom the core and toward the subcenters, the value of accessibility changes accordingly, as do the residential boundaries and money wages net of transport cost. No simple wage gradient can thus be derived a priori and the initial assumption of the paper appears plausible.

Therefore, in considering labor cost variations over space, the most realistic case among those treated is one which assumes both fixed coefficients between machine ry-equipment and labor and a fixed proportion of lowskill labor within the work force of hypothetical firms considered. As seen in Part III, the variations in average payroll are roughly 1 percent in favor of core locations, assuming low-skill jobs equal 10 percent of the total labor of the firm. Translated into the frameworkadopted for the hypotheticalfirms, and explored in Part V, this would imply a parallel absolute change in net operating profit of roughly $2-3$ percent.

Part III, with its considerations of variations in land prices, the price of government services and the variation in wage and labor costs, sets the ground work for the exploration of building space costs. In Part IV the potential for a trade-off of $S_{j}$ for $L_{j}$ is explored. If institutional barriers are ignored, including zoning regulations which specify ground floor to land area 
ratios, and if questions of multilevel operational efficiency are set aside, then it appears theoretically possible to vary the relationship between land inputs and structural capital inputs along a given isoquant. Even then, the capital input requirements needed as land inputs are reduced appear to rise very rapidly. When institutional constants and operational efficiency considerations are introduced, there appears to be good reasons why multilevel construction for manufacturing usage is rare. It thereforefollows that the annual costs of space (including the accompanying property tax burdens) for the hypothetical firms will be lower in the suburbs. Part V provides data for the hypothetical firms which suggest that these differentials are sufficient to cut the absolute level of net operating profits in the central cityby 15 to 30 percent over those prevalent at suburban sites. It becomes clear that there would be no tendency to reconsider the decision to locate in suburbia for labor cost reasons. As always, it should be emphasized that the features of the model firms are not universally applicable.

\section{PART III: EXISTING INTRA URBAN COST DIFFERENTIALS: LAND, GOVERNMENT SERVICES, LABOR}

\section{CORE LAND USE AND EXISTING LAND PRICE DIFFERENTIAL: INTRO- DUCTION}

From the viewpoint of typical manufacturing firms, land in urban areas has become an increasingly homogenous input. Yet, as noted below, land prices facing these firms still differ significantly between central city and suburban locations. The clarification of this apparent paradox requires a careful separation of the determination of urban land prices in the long run equilibrium from those factors affecting the spatial variation in the short run. In the short-run, the analyst must cope with the presence of fixed capital stocks in the core city, and with the related costs of moving for established firms. Existing theories of location implicityignore these short-run forces, projecting long-run equilibrium solutions, which require a complete adjustment of the capital stock and all established firms, to observed changes in technology and relative factor prices. 14 This comparative statics approach abstracts from the fact that land-use patterns, at any given point in time, are affected only incrementally be comptemporaneous cost conditions as viewed by de novo firms.

Capital stocks directly affect the behavior of existing manufacturing land users. Those stocks, even if "outmoded" in the view of de novo firms, do provide some types of users with building space which is not cheaply reproduced by new construction at other locations. Also, those stocks, as evidenced by the results of the Boston survey, are associated with particular networks of suppliers and customers which would be disrupted by moves. Add to this the costs of "transfering" plant and equipment: the sale price of plant and equipment will most probably befar less than the present value of earnings from the central city plant, because buyers may not be found who will ignore the fact that returns on an investment in the manufacturing activity are greater in suburban locations. The costs, when compared to the benefits of moving to suburban sites (the increased earnings per dollar of new capital stock, appropriately discounted), may prompt very different reactions from those of firms making de novo decisions.

Capital stocks also affect the behavior of de novo firms. They are not likely actively to reshape the land use patterns in "obstructed" a reas through demolition and new construction because of the cost involved. Given the dearth of central city vacant land, the impact of contemporaneous technology is most likely to be felt in suburbia. 
These general factors help explain why there is no noticeable tendency for the process of "suburbanization" to release large amounts of previously utilized space in the core, spurring demolition and expanding the supply of vacant land. This rapid expansion of vacant land is a prerequisite for central city industrial land prices which are not noticeably higher than those prevailing in suburbia.

\section{THE SUPPLY AND DEMAND FOR INDUSTRIAL LAND IN BOSTON}

Boston falls into the category of land-scarcecities. An intensive review of the evidence ${ }^{15}$ suggests that the following price ranges were characteristic of prime vacant land in 1970: \$3.50-\$4.50 per square foot for the city of Boston; \$1.15-\$1. 30 per square foot for the "firstalternate area"along the industrial band known as route 128 (lying 10-15 miles from Boston's C. B. D.); and $\$ 0.70-\$ 1.00$ per square foot for land along the band which has become the object of most recent development, route 495 (lying 25-30 miles from Boston's C. B. D. )

These summary comparisons hide significant variations. In particular, there is considerable temptation to underestimate the price of land in each area. Two examples will illustrate this. First, a 1970 unpublished survey made by the Economic Development and Industrial Commission in Boston uncovered a number of centrally located sites for sale at between $\$ 1.75$ and $\$ 3.00$ per square foot. These sites, on closer inspection, exhibited one or more of the following problems: small size (under 2 acres); highly fragmented ownership ( 5 or more owners); unsuitable land fill; partly submerged property; and rocky terrain. Second, along route 495 the lowest priced suburban sites (\$0.10-\$0.15 per square foot) had unsuitable, rocky terrain and lacked municipal sewer connections.

Corresponding to these area price ranges are estimates of vacant land available for industrial development. There is both an absolute and relative scarcity of vacant industrial land in the central city. In fact, there are, at most, 220 acres of land available for industrial development and possibly less than ten times that amount for all uses, including expanded open space. 16 This being the case, it follows that one need only demonstrate absolute and relatively small demand for vacant land to establish why core industrial land prices should be a multiple of land prices of even the developed suburban areas. Both suburban bands considered have thousands of acres presently vacant and zoned for industry, while annual demand for vacant industrial land fails to exceed 100-200 acres.

The potential supply of land can be increased only by considering conversions from obstructed use. This does not improve the central city's position in price comparisons with suburban areas. If industrial obstructed land is considered, then relatively low annual rent per building squa re foot yield capitalized land values of between $\$ 3.00$ and $\$ 6.00$ per squa refoot. When demolition costs a re added, land values can easily scale up to $\$ 8.00$ per square foot. 17 In fact, the experience of the Boston Redevelopment Authority in the acquisition and demolition of land in blighted residential areas suggests costs which also exceed the highest prices of industrial land in suburbia by a wide margin. 18

There is no accurate compilation of the annual rate of vacant land consumption in the city of Boston. The Boston Redevelopment Authority has made estimates for the period 1960-1975 which assume the elimination of all vacant land by 1975. If one excluded land for projected recreational uses and manufacturing-warehousing, the annual rate of comsumption would equal 100 
acres of vacant land, with a residual of the original 3200 vacant acres left at the end of the period. 19

An alternate and very rough approach to making such agg regate estimates focuses on the annual rate of new construction as revealed by the building permits authorized by the city of Boston. The annual rate of new construction is running at roughly $\$ 270$ million per year (1971 dollars); through various rules of thumb, ${ }^{20}$ one can derive building square footage and corresponding landsquare footage from the data which suggest that total land absorption in Boston averages 125 acres per year, both vacant and obstructed. This implies the B. R. A. estimates on vacant land consumption are overdrawn, though adequate information on the use of obstructed land is not available. Nevertheless, the B.R.A. estimates points to the type of pressure exerted on the city's vacant land supply.

The sources of this pressure can be outlined generally. First, there is obviously some demand for industrial space by manufacturing concerns whose ability to utilize old loft space and/or labor-intensive processes emphasizing low-skill, low-wage labor may be atypical. These firms may constitute a very small percentage of firms making locations do novo in the Boston area; yet they can generate demand which is significant relative to the supply of vacant land. Second, the distribution of firms cited above (between the overwhelming majority that find differential costs of operations favorable to suburban locations and a residual number of firms) may not be representative of the situation facing established core firms contemplating the alternative of moving to suburbia or expanding incrementally on adjacent sites. The E. D. I. C. survey discussed in section I reveals that the costs of moving are large; in particular, among reasons cited for not moving, 25 percent could be classified under the heading of "inertia." Adjacent expansion to add small amounts of working area or to make way for some off-street parking facilities may be the rational course to take for a large number of established firms, generating a second source of demand. One item suggestive of the differentials involved can be found in a study of core city loft space: users of this type of space, generally regardedas obsolescent by users of continuous production line technology operate in a market where space rents for $\$ 0.50$ to $\$ 1.50$ per building square foot per year, while new suburban space rents for $\$ 3.00$ per square foot. 21

It is interesting to examine, in this regard, the possibility suggested by fragmentary evidence on manufacturing space users. It appears that technological and production format changes introduce a small secular bias in favor of a greater number of square feet per worker. A rate of growth in space needs perworker of as little as 1 percent per year would act to effectively neutralize the impact of declining manufacturing employment on the square footage demanded by manufacturers within the city of Boston. ${ }^{22}$ This might help explain why, in the aftermath of suburbanization, the re is both very little vacant land and relatively smallamounts of vacant manufacturing building space. Specifically, according to unpublished EDIC data, the number of square feet of vacant building space for manufacturing amounts to $2+$ million. Assuming that there roughly was 40 million square feet of space in 1947 (100, 000 workers $=400$ square feet in space requirements perworker), that represents a 5 percent vacancy rate with respect to the original figure. Even if there has been some reconversion to vacant land and some spillover of growth from othe $r$ employment categories to absorb potential vacant building space, there still appears to be remarkably little evidence of the fact that, between 1947 and 1970, the city lost 27,000 manufacturing jobs, or roughly 27 percent of its manufacturing work force. 
As noted, the demand for land depends on the interacting needs of manufacturing and non-manufacturing firms. In spite of forecasts of across the board declines in core activity, expansion in the non-manufacturing sectors in recent years appears firmly based on two factors. First, there are "industries" which are region-serving, and thus responsive to the increasing population and average incomes of the Boston area; location in the core results from an ability to make use of the positive economies of agglomeration. Second, as argued below, the re is some justification for renewed expansion of local-serving firms, on the basis of stablizing population and rising real family incomes. The mostimportant space users sensitive to the se changes include hotels, motels, restaurants, retail outlets, educational and health facilities, and expanded governmental activities.

Evidence of the expansion of non-manufacturing establishments can be found in annual building permit data and in fragmentary land survey information. In particular, a follow-up to the original $1970 \mathrm{E}$. D. I. C. industrial land inventory, made within 6 months of the first, revealed that 75 of a potential 220 vacant or underutilized acres zoned for industry had been acquired by non-manufacturing interests. Along with these "commerical" interests. one additional user of industrial land should be mentioned: semi-autonomous public agencies. According to Boston Redevelopment Authority sources, the Massachusetts Port Authority and the Massachusetts Bay Transit Authority together control over 300 acres of industrial land which is either vacant or largely so. Both have the financial resources to hold land for future use; the Port Authority, in particular, has ambitious plans to expand its airport facilities and to revitalize the dormant seaport industry and has undertaken an ongoing program of land acquisition in industrial a reas.

Some observers have pointed to Boston's decreased population over the last two decades as a mechanism through which vacant land (including land rezoned for industry) could be expanded. An analysis of existing data 23 that, whereas the 1950 's might have provided grounds for such a presumption, the 1960 's do not. Using 1950 as the base year for calculating percentage changes, one finds that two thirds of the 21 percent decline in population took place in the first decade and, more significantly, that 90 percent of the decline in household units occurred in that same decade. In fact, during the 1960 's the rapid increase in real incomes appears to be behind the 5 pe rcent decline in per occupied unit residential density which kept the decrease in household units to a mere 2 percent. Even this fails to detect the impact of the extensive federally-financed residential redevelopment program within Boston's blighted neighborhoods which has placed large portions of central Boston into renewal districts whose land values a re buoyed by direct federally-supported acquisition or the expectations of future suchacquisitons. Residential areas containing 2500 acres and more than 100,000 inhabitants are now part of this effort, including every major blighted area. Within this area, especially in the "captive" housing market of the blacks, the Federal effortwill have the long-range effect of supplementing the trend toward lower densities per unit and fewer units per acre of land, a factor again likely to neutralize the effects of population losses on the supply of land for all types of development. 24

\section{THE DIFFERENTIAL IMPACT OF REAL ESTATE TAXATION}

Property taxes are the major source of revenue for Massachusetts cities and towns, with over 60 percent of a rea expenditures being financed by taxes on buildings and land. 25 An examination of the tax rates over space will reveal considerable disparities between the city of Boston and the typical suburban community. This is the case even after nominal tax rates have been allegedly converted into real tax rates by multiplying the former by the ratio 
of assessedvaluation to presumed marketvalue of the property. Attempts to verify these assessment ratios is not easy, for Boston has a vested interest in representing that ratio to be close to 100 percent. State aid is distributed, in part, on a proportional basis to each community according to real or full value tax rates established by the State Tax Commission. And, according to that commission, Boston appears deserving of aid. Its assessment ratio is represented as .84 and its full value tax rate is listed as 12.15 percent per annum, while suburban full value rates range from 3 to 5 percent perannum. ${ }^{26}$

Interviews with real estate brokers, representatives of the Massachusetts Taxpayers Foundation and the State Tax Commission, information obtained from within the Boston Assessor's Office, and the work of Oldman and Aaron $^{27}$ suggest that Boston's tax efforthas been exaggerated whereas suburban rates appear roughly correct. Boston's ability to depart significantly from published assessment ratios is tied to its ability to exercise disproportionate political power within the State regulatory agencies in its pursuit of State aid. Other reasons that help explain the better record of suburban communities include the complexity of property composition (50-85 percent single family dwellings versus 10 percent for Boston proper) 28 and the fact that suburban commerical-industrial properties are relatively new, with easily verifiable replacement values.

For the purposes of this paper, it is assumed that the real or full value tax applied to manufacturing firms in Boston is 5 percent, while 4 percent is taken as roughly representative of tax rates found in the suburban areas. This results in more than an absolute 25 percent differential in yearly taxes because of the existing differentials in land prices over the urban area.

\section{THE QUESTION OF INTRA-URBAN WAGE DIFFERENTIALS}

The impact of tax and land price differentials on location a re all the more important becuase of the apparentabsence of any labor cost offsets. Reaching any conclusions in this area is difficult not only because the theoretical wage gradient arguments are inconclusive, but also because the total number of published empirical studies on wage differentials in metropolitan markets is miniscule. In analyzing wage data, it is clearly inadequate to compare the average wage of production workers in the central city and the suburbs. This yields no measure of area advantage in the provision of particular jobs services, for wages could be the same by occupational category and still the average wage could differ because of variations in industrial composition. Even the use of individual industries with presumed homogeneous labor requirements for comparative purposes does not resolve the issue. Noll 29 claims that high wages prevail in central city areas and uses individual industry Census data for New York and Philadelphia to prove his point; in 85 percent of the comparisons the industry wage differentials in favor of suburbs or central city were 5 percent or less and appear to demonstrate very little. Martin Segal ${ }^{30}$ made a similar study of 28 industries and services in the New York area; if garment and related industries (which rely on exceptionally low-wage labor) a re excluded, 19 industries remain. Of these, 10 suburban industries had average wage levels with 5 percent of those prevailing in New York City ( 5 industries exceeded New York City levels, 5 fell short). Of the remainder, 5 suburban average industry wage exceeded and one fell short of the equivalent central city average industry wage. Segal therefore implies what Noll denies. ${ }^{31}$

More recently Rees and Schultz made a study of the Chicago metropolitan area and dealt explicitly with individual occupations. The authors did 
not address themselves specifically to the issue of central city versus suburbs, preferring to analyze the impact of movement (direction unspecified) on metropolitan area wages. One summary calculation made in the study for various occupations involved the value in added wages of travelling 10 miles to work as compared with one block, while controlling for such "individual" variables as age, seniority, schooling, other training, color and origin, sex, and marital status. In two unskilledoccupations the measures isolated nonwhite workers who apparently worked in suburbia for non-white material handlers, the impact of a 10-mile trip was equivalent to roughly 8 percent of the sample study mean earnings for that category. Again, a study of nonwhite janitors traveling over 9 miles to work versus those who do not, yielded a coefficient of this distance dummy variable equivalent to approximately 7 percent of the sample study mean earnings for all janitors. For skilled and semi-skilled occupations, no obvious direction of movement could be discerned from the data presented.

The same authors incorporated into their regression analyses a dummy variable to take into account a firm's location in either a "base area" or the rest of the region. Unfortunately, the "base area" did not coincide with the central city and, for different occupations, was defined to include smaller or larger portions of the suburban metropolis. Thus, their conclusions do not illuminate the questions raised in this paper.

The data obtained for this study are sketchybecause gathering wage data on a disaggregated basis, by location, is difficult. One must deal with the absence of official information, the fact that selective unionization and large employers may distort area rates, and the problem that uniform employment categories are hard to establish. In order to assemble data with some guarantee job description, use was made of information assembled by the National Metal Trades Association and this, in turn, was checked against the confidential survey of the Federal Reserve Bank of Boston. The information was reviewed by personnel officers of area manufacturing firms. In each case the results were similar. Undifferentiated area-wide rates we re said to prevail for skilled personnel, whose wages tend to exceed \$3.50 per hour (1970). The wages of unskilled workers such as janitors, laborers, and materials handlers were $10+$ percent lower at central city locations. Finally semi-skilled pay scales rarely diverged by more than 3-4 percent, with lower rates again applicable to the central city.

For the typical manufacturing firm, even given fixed capital-labor proportions, an across the board reduction in labor costs for all laborgrades of even 10 percent would have a noticeable location effect. For illustrative purposes, assume a typical firm ${ }^{32}$ incurs labor costs equivalent to 35 percent of its total revenues and that it nets the equivalent of 10 percent of revenues in operating profits before taxes. A one-tenth decline in labor costs, through a shift in locations, all other things being equal, would increase net operating profit from the equivalent of 10 percent of revenues to 13.5 percent of revenues, a rise of more than one-third. Thus, even if the annualized cost of building space were considerably higher at the lower wage sites than at alternate locations, aggregate costs per unit of output might well be lower.

The wage differential uncovered, however, applied la rgely to low-skilled workers. Yet the typical manufacturing firm has a built-in preference for "standard" workers, whose performance record establishes the optimal capital intensity of operations. A deterioration in labor quality therefore would be ruled out. In fact, fragmentary untabulated data for both Boston and its suburbs, collected by E. D. I. C., suggests that most manufacturing industries 
hire low skill labor (roughly defined as earning less than $\$ 5,000$ per year in $1970)$ to perform ancillary tasks. These laborers account for no more than 10 to 15 percent of the firm's laborforce. There is little evidence that lower wages for unskilled workers in the central city prompt the "mainstream" firms to increase significantly the percent of such labor that is hired.

For illustrative purposes, the slight variation in the wages of semi-skilled workers can be ignored, and two grades of labor--skilled and unskilled-can be assumed to exist. The first grade accounts for 90 percent of the firm work force and averages $\$ 8500$ in wages per year; the second comprises 10 percent of the firm's labor and averages $\$ 4500$ in pay per year. The weighted average wage is therefore $\$ 8100.33$ A 10 percent cut in low skill wages reduces the weighted average wage by 0.5 percent. Following earlier assumptions, labor costs, expressed as a percent of revenues, would be cut from 35 percent to 34.8 percent. All other things being equal, net operating profits would rise from an equivalent of 10 percent of revenues to 10.2 percent, an absolute increase of 2 percent. Given the fact that building space costs at those same sites are annualized capable of cutting net operating profits by 15 to 30 percent over suburb sites, this "labor advantage" is hardly significant.

There appears to be a rational justification for ignoring the use of this pool of low wage labor, in the absence of substantial upgrading of its members to meet pre-existing job category requirements, (even entry-level jobs with built-in advancement). Various institutional barriers, detailed by Doeringer and Piore 34 among others, bar such a process in the absence of a fairly massive public subsidy effort.

\section{PART IV: MULTILEVEL VERSUS SINGLE STORY CONSTRUCTION THE POSSIBILITY OF A LAND-STRUCTURES TRADE-OFF}

\section{THE PROBLEMS OF COMPARATIVE COST ANALYSES}

If the existance of price differentials between core and suburban land is accepted, then the desirability of substituting structures for land should be explored. Specifically, the feasibility of multilevel buildings for manufacturing use within central city areas must be considered.

Unfortunately, the evidence available for an accurate evaluation of multilevel space is poor. ${ }^{35}$ Most multilevel manufacturing space found in today's older central cities was constructed between 1899 and 1920 . As a result, it is characteristically devoid of all but minor off-street loading and parking facilities. The buildings a re likely to have narrow unimpeded space (less than 20 feet $\times 20$ feet); floor loads may sometimes be below the 150 pounds per square foot deemed necessary for the average manufacturing operations today. Ceiling are likely to be low, sometimes less than the 12 foot height required to allow fork-lift trucks to carry minimum 2 pallet loads. Plumbing, lighting, and heating-ventilation-airconditioning standards are likely to be inadequate. Finally, elevators are often slow (under 75 feet per minute) and/or inadequate in capacity (under 8,000 pounds). For the above reasons, the multilevel-single story comparisons which follow are hypothetical, though they reflect the advice of various architectural and engineering firms in Boston.

\section{COMPARATIVE COSTS OF SINGLE-STORY AND MULTILEVEL SPACE}

To illustrate the additional structural capital requirements of multilevel space, a comparison can be made between two structures, each with, say 80,000 square feet of space, one single story and the other, multilevel. 
Costs, as seen in Table 1, are broken down into two categories: shell requirements (i.e. walls, roof, floor) and upgrading requirements to make the shell usuable for manufacturing. The multilevel structure used forillustrative purposes includes 4 floors though, as noted below, the cost comparisons are relatively insensitive to the number of floors used. Cost differentials appear both in shell construction and in upgrading work. In building a multilevel shell, there are extra costs involved in providing adequate floor load capacity above ground. There are also extra costs associated with added exterior wall area; thus, for example, a rectangular, single story structure with 20 foot ceilings and 80,000 square feet of space has 24,000 square feet of wall space, while a multilevel 4 story structure will have 48,000 square feet of wall space, and so forth. Finally, the addition of stairs and stairwells to a highrise structure increases costs. The only offset to the costs is the small savings incurred in roofing multilevel space. The differential between the two types of construction is extended in the shell upgrading phase, when ex-penses associated with elevators must be dealtwith. A four-story building with 80,000 square feet will require 2 passenger elevators travelling at 200 feet per minute and 4 -ton freight elevators operating at a minimum speed of 150 feet per minute. These requirements would increase per building square foot to a total which is somewhat more than $\$ 4.00$ per square foot over the cost of comparable single-story space. Rapid calculations will show that this additional cost of multilevel space is rather insensitive to building specifications. Buildings with between 3 and 6 floors must include a similar number of elevators, though perhaps some economies can be expected in use of somewhat slower speed and lower capacity for 3 floors, while the reverse is true for buildings with 5 to 6 floors. Beyond that height, additional passenger and freight elevators must be added to maintain similar standards. Furthermore, extra shell construction requirements are marginally lower for 3 floor structures, but they increase rapidly for 5 floors and above. What might appear to be an exception to the rule, is not. Two level structures are relatively costly. This is because they incur relatively high costs in exterior walls and multilevel floor supports. These two items alone add $\$ 1.30$ to the per square foot cost of single story space. The additions of two staircases for pedestrian traffic would bring the per square foot costs to more than $\$ 16.40$ per square foot. If the second floor is to be fully integrated into manufacturing operations through the use of freight elevators or some elaborate conveyor system, the total per square foot costs might well exceed $\$ 18.00 .36$

\section{COMPARING SINGLE AND MULTILEVEL STRUCTURES}

To analyze the trade-offs between land and structures, certain preliminary assumptions must be made. It assumes that there are two types of structures available to the manufacturers, as outlined in the previous section. The intensity of land use at central and suburban locations is standardized for the purposes of this paper. Firms locating in the central city can legally use very high building ground level-to-land coverage ratios. However, there are sounds reasons for keeping the ratio at 50 percent inorder to accomodate effectively site transportation and parking needs. This feature allows ancillary service levels associated with multilevel structures to be somewhat comparable to those of single story structures planned for suburbia. Suburban communities, in fact, tend to impose low building-to-land coverage ratios, one-to-three being the norm.

The manufacturer considering the use of multilevel space in the central city as a means of offsetting the high cost of land is faced with the fact that such space is costlier to construct perbuilding square foot than single story space at all locations. For the purpose of this paper, that disadvantage is fixed at $\$ 4.00$ per building square foot. Given the range of land prices prevailing in the urban area, the manufacturer must make a series of compari- 
sons. First, single story suburban space is contrasted with multilevel central city space and the differentials in land component costs per building square foot in favor of multilevel space are observed. Then total construction costs for each type of structurea re incorporated into the calculations to yield differentialtotal costs (land and construction) per building square foot. Tables 2 and 3 detail the results. For example, when suburban single story structures built on $\$ 1.00$ per square foot suburban land is compared to a 4 story central city building constructed on $\$ 4.00$ per square foot land, the savings in land component costs to the central location structure amount to $\$ 1.00$ per building square foot. Yet that same structure costs $\$ 4.00$ per building square foot more to construct than the suburban space. Therefore, as noted in Table 3, the total cost differential per building square foot favors suburbia by $\$ 3.00$. Or again, if the suburban single story structure is built on $\$ 1.25$ per square foot land and the central city 4 story building is placed on $\$ 7.00$ per square foot land, then the differential in land component costs in favor of the core equals $\$ 0.25$ per building square foot. Yet, given the higher construction costs per building square foot of multilevel space, the total cost differentials per building square foot favors the suburbanstructure by $\$ 3.75$ per building square foot. In fact, Table 3 illustrates the contention that, at prevailing land price ranges in the central city and suburbia, multilevel central space would continue to be costlier in the aggregate than single level suburban structures. Multilevel construction would tend to narrow the gap between suburban and central city space costs. It would create cost differentials which would favor the suburbs less decisively than if single story structures along were considered at alternate sites.

\section{OPERATIONAL EFFICIENCY OF MULTILEVEL STRUCTURES: GROSS VERSUS USABLE SPACE}

Before making a direct comparison between differential total costs per building square foot in favor of suburbia, using multilevel space in the central city (Table 3) and the differential costs when single story space along is used throughout the urban area (Table 5), an additional step must be taken. Table 4 recomputes the results of Table 3 by taking into account that multilevel structures are less efficient in providing usable space. As a rule of thumb, for equivalent amounts of gross space, single story structures provide 13 times the amount of usable space found in multilevel structures. Thus Table 4 demonstrates the differential total costs in favor of suburbiaper building square foot of usable space. Now it can be seen that if the differentials in Table 4 are expressed as percentages of those in Table 5, then, on the average, the use of multilevel structures in the central city would cut the differential cost advantage of suburbia to no more than 50-80 percent of what it would be if single structures along were used in the entire urban area. 37

\section{OPERATIONAL EFFICIENCY OF MULTILEVEL BUILDINGS: TIME- MOTION PROBLEMS}

The efficiency of multilevel space, measured by its ability to meet inflow outflow standards set by single story operations, is harder to determine. In the absence of new manufacturing space in multi-story buildings, one can only speculate whether the use of off-street parking together with loading platforms at the rear of the building which have direct access to freight elevators, is enough to provide efficient exterior circulation. Within the structure, in an optimum model, reliance can be placed on elevators and on fork-lift trucks for the horizontal transport needs. In this regard, there is still controversy; the literature abounds with "gee whiz"ideas for enhancing the competitiveness of multi-story space. Thus, for example, one author advises, "Look into towline conveyors to link floors into an efficient process flow. Carts can now rideup inclines to the floor above or even ride elevators 
automatically. New vertical pallets lift, load, unload, and dispatch on a programmed basis to give continuous conveyorized flow over three or four floors." 38 Another source has suggested that "to increase materials flow; elevators (can be) used for raising materials only. Items up to 30 inches square have been chuted economically and satisfactorily for many years. Or if goods may be received by chute to the basement, a night shift could be employed to deliver materials to production areas, that elevators could be used for shipping and personnel during the day hours. Conveyors, drag chains, and other handling equipment may all be combined and coordinated to solve problems." 39 For the purposes of the study, however, the more conventional designs were accepted on the basis of advice from various engineering sources; as one author pointed out, consideration of "automated systems such as conveyors, chain-veyors, monorails, etc. . . (can be) eliminated because of their low speed, low volume of pounds transported, high maintenance cost, and limited flexibility. 140

The efficiency of modernmultilevel manufacturing structures, using elevators and fork-lift trucks, remains a moot question in the absence of actual examples. Casual empiricism suggests that full parity with single story structures will be difficult if truck delivery requirements and material handling needs are relatively high, and if the goods produced are relatively buclky and of low value added. In any case, the re are very few industrial operations benefiting from multilevel structures. The reintroduction of such buildings is, therefore, unlikely to be a feature of the foreseeable future.

\section{THE REHABILITATION OF MULTILEVEL SPACE AS AN ALTERNATIVE TO NEW MULTILEVEL CONSTRUCTION}

If multilevel space appears to pose problems which fail to make it competitive with suburban single story space, then perhaps existing multilevel space can be modernized to provide a partial answer to the problem of making the central city attractive to more manufacturing firms. Unfortunately, there are no good estimates on the total number of square feet of multilevel space in the city which can be rehabilitated (i. e. buildings that meet modern column spacing and floor load requirements). In any case, a structure which met minimum standards could be stripped to its shell and ungraded to modern shell standards by roughly $\$ 2.00$ per square foot. Remodeling would involve an additional expenditure of about $\$ 9.00$ under the assumptions in Table 6 . To approximate modern parking a rea needs, it might be necessary to acquire adjacent structures, demolish them and pave over the land. This additional operation, under the assumption that the demolished structure is obsolete and vacant, would add approximately $\$ 2.50$ to the per building square foot cost of the rehabilitated structure, for a total per square foot cost of about $\$ 13.50$. If the remodelled structure had to be purchased prior to its alteration, then additional costs would be incurred which could amount to $\$ 5.00$ or more per building square foot. The total per building square foot cost could rise even further if structures demolished for parking had some use value, or if the remodelled structure has any unusual problems. New multilevel structures are therefore probably no more expensive than rehabilitated ones. The rehabilitation route is no panacea and should be followed only selectively, even when operational difficulties a re set aside.

\section{PART V: RENTAL EQUIVALENT COSTS IN CENTRAL CITY AND SUBURBAN LOCATIONS}

\section{INITIAL ASSUMPTIONS FOR BUILDING SPACE COST COMPARISONS}

The information on the spatial variations in land costs, building costs, 
and the costs of government services can be summarized by intra-urban comparisons of rental equivalent building space costs. Underlying this analysis is the use of hypothetical industrial development projects at core and suburban locations in Greater Boston. A developer is assumed to buy land, erect structures, and lease them for a rental cost which includes the annual costs of land, structures, taxes, and utilities. No consideration is given to cases where completed buildings are sold to the user, or to the individual firm acting as its own developer. With appropriate transformations the rentals information can yield data for these latter cases.

One can made comparisons under two sets of assumptions, one coreoriented and one suburban-oriented. This is necessary because of the different institutional requirements with respect to building-to-land ratios. Suburban industrial space users operate under a legal constraint to provide, on the average, three square-feet of land for every square foot of building; the bulk of this land can be used for parking areas, but it is not available for plant expansion. In the core, there are very minimum setback requirements which, in essence, allow use of all but 90-95 percent of the land site. This, however, was not deemed a feasible ratio because any "typical core site" should allow for relatively abundant parking and truck holding areas. A core building with 200,000 square feet, for example, would require one car per every third employee. 41 If each employee is assumed to occupy 300 square feet of floor space, then this implies one parking spot for every 900 square feet of building or 222 spaces. Since each car can be assumed to use 300 square feet for parking and maneuvering corridors, the required paved areas amount to about 67,000 square feet. Trucking needs are harder to estimate. 42 The most common rule of thumb seems to be one truck space for every 5,000-10,000 square feet of building; each trailer truck needs 600 square feet for parking plus 600 square feet for maneuvering, or a total of 1,200 square feet per vehicle. For 200,000 square feet of building space, this results in 24-48 truckspaces, or 29,000-58,000 squarefeet. City setback requirements in the same case would add 20,000-40,000 square feet of land. Adding these various requirements together produces a tight $60 \%$ coverage ratio. This analysis assumes a 50\% coverage to allow for any contingencies, such as rail spurs or extra car parking needs.

Because of this building-to-land diffe rential, comparisons of rentals between suburbia and the central city must be made with one set of constraints at a time. Thus Table 7 and 8 juxtapose the results of using land of varying prices to arrive at plants with a 50 percent coverage ratio and then with a $331 / 3$ percent coverage ratio. In both cases similar assumptions are made about financing charges per year. It is assumed that land costs are financed over 25 years at $91 / 2$ percent interest for a yearly constant (or equal payments rate) of 10.5 percent. 43 Building costs a re as sumed to be roughly the same in core and suburban locations; namely, $\$ 15.00$ per square foot of equivalent single storyspace. These structures, built by the developer, are then leased to clients. The credit worthiness of these tenants in the eyes of financial sources determines the terms on which mortgage money is provided. If "suitable" clients commit themselves to long leases (say, 10 years), it is possible to get a 25 year mortgage on terms comparable to those cited for land. 44 This process does depend, among other things, on the developer's ability to subordinate the land rentals to the lender. The lender then bases his evaluation of the "collateral" on the ability to take over and collect the annual building and land rents.

\section{A HYPOTHETICAL QUANTIFICATION OF RENTAL DIFFERENTIALS}

The first three tables in this section present detailed hypothetical rental information at each of four sites, two in suburbia and two in the core. Each 
table differs from the other two in building space toland area ratio as sumed to prevail. Thus, for example, in Table 7 a ratio of $1: 2$ is employed for all four sites though it is applicable, in reality, only in the core city. In ascending order (from the cheapest suburban land to the costliest core sites), the rentals derived range from $\$ 2.06$ per square foot per year to $\$ 2.12, \$ 2.78$, and \$3.51. These preliminary calculations exclude utility and property tax charges and are therefore net rentals. Table 8 repeats the calculations at each typical site using the $1: 3$ building-to-land ratio characteristric of suburban areas. The net rentals now range from $\$ 2.17$ and $\$ 2.27$ to $\$ 3.27$ and $\$ 4.34$. Table 9 presents gross and net rentals at different locations, using characteristic local building-to-land ratios for each site. Net rentals now vary from $\$ 2.17$ and $\$ 2.27$ to $\$ 2.78$ and $\$ 3.51$.

In reviewing the three tables, it becomes apparent that attempts to duplicate suburban densities in the core would be prohibitively expensive. If the core site involved obstructed land, then the derived net rentals would be twice as high as those based on the cheapest suburban land. The differentials shrink, especially when relatively expensive core land is involved, if attempts are made, hypothetically, to duplicate high core densities in suburbia. The difference between the highest net rentals in the core and lowest net rentals in suburbia is cut by 30 percent when compared to the case where suburban densities a reutilized at each site. The differential in rentals is smallest in the "real world" case where suburban development is restricted to relatively low densities while central city industry is free to find its own level subject to minimal setback and parking need requirements. The gap in net rentals between structures on obstructed core land and structures on the cheapest suburban land is now equal to just over 60 percent of the difference reported in the first case, where suburban densities are used.

In Table 10, these differentials, along with those resulting from other central city-suburban site comparisons, are translated into percentages. Suburban site rentals are used as the base. Among the more revealing features of Table 10 is the fact that the comparison most favorable to the central city still yields net rentals which are almost one-quarter higher than those in suburbia. This case involves the use of vacant centralcityland, suburban sites along well-developed route 128, and prevailing building-to-land ratios at each site.

Table 10 also illustrates the fact that the addition of yearly property taxes accentuates the gross rental gap. Net rentals are 23 to 63 percent higher at central city sites than at suburban locations. Gross rentals, which include net rentals, utility charges, and local taxes, are 29 to 75 percent higher at central city sites.

The above examples of core area disadvantage are optimistic. Vacant land is of only short-term significance to the city of Boston. Furthermore, any discussion of route 128 space should include the quotation of rentals for "second-hand" building space built over the last few years and presently vacant. Neither the route 495 area nor the core area have relatively new vacant building space in their "inventory." Along route 128, there are varying amounts of older space renting (net) for up to $\$ 0.50$ per year below those rates cited for newly constructed buildings; at present, depressed economic con ditions have freed up to one million square feet of older space for rental. ${ }^{45}$ By way of comparison, the central city can count on no oldervacant building space other than that constructed fourdecades ago or before. The low rents for older space in the core represent no challange to suburbanaresa and provide very little incentive to the typical manufacturing firms which would find such space obsolete. 

OF MODEL MANUFACTURING FIRMS

As mentioned in Part II, an attempt was made to study hypothetical firms in different industries presumed to locate in newly constructed suburban buildings and ranging in employment from 100 to 500 workers. They were chosen as typical of industries whose investments in machinery and equipment per worker were neither relatively low (as in apparel products) nor relatively high (petrochemicals, aircraft parts), whose average yearly payroll per employee was relatively high; and whose growth potential was fairly good. The data gathered in Tables 11 and 12 were obtained through interviews with financial officers of existing area firms whose employment ranged from 100 to 500 , and through information provided by the Electronics Industries Association, the Computer Peripherals Association, the Printing Industries of America, and the National Metal Stamping Association. The estimates are of the roughest sort, both because of the anxiety of the contacted parties over possible breach and because the effort is purely illustrative. ${ }^{46}$

Tables 11 and 12 have been used to construct the remaining tables, which express cost differentials between the central city and suburbiaboth in terms of dollars per average worker per year and in terms of changes in net operating profits. Net and gross rentals at each site can be expressedas dollars per worker peryear by making certain reasonable assumptions about the average building space utilized per worker (13). This rental data per worker can be expressed as a fraction of average annual revenues perworker in particular industries (Table 14).

The calculations in Table 14 can be utilized to evaluate the impact of shifts in location. Bydefinition revenues $=$ gross rentals + other costs + net operating profits. At a typical suburbansite, the typicalfirm can be assumed, for illustrative purposes, to incur costs such that net operating profit is equivalent to 10 percent of revenues. Obviously, as Table 13 shows and common sense would dictate, this varies by industry and, to some degress, by particular suburban site. Now, if the firm moves from suburbia to a central city location, then the components of gross rentals increase from a specified level (also expressed as a precent equivalent of revenues) to a higher level. Sinceall other types of costs are taken as given, the only offset (again expressed as a precent equivalent of revenues) is a decline in net operating profits. Thus, for example, if gross rentals were to increase from costs equivalent to 3 percent of revenues to costs equivalent to 6 percent of revenues, then would net operating profit decline from an equivalent of 10 percent of revenues to 7 percent of revenues, a cut of 30 percent.

The burden of real estate taxes does not vary significantlybetween firms in different suburban areas, but the impact for sites in central city areas is anywhere from 50 to 100 percent higher than at suburban sites (Table 14). Isolated from other components of gross rentals, this differential amounts to cutting net operating profits of the typical firm moving from suburbia to the central city by 5 to 10 percent. Net rental comparisons also generate substantial differentials between central city and suburbs. Net rentals at central sites are 25-60 percent higher than at suburban sites. This has the effect of cutting net operating profits by 7 to 17 percent for the typical firm that moves to the core. The interaction of property tax and net rental differentials yields gross rental differentials, the best measure of the disadvantage of core sites for manufacturing firms. As seen in Table 14, the gross rental differential is high enough to cut net operating profits for the firm moving to the central city by 15 to 30 percent. 


\section{PART VI: CONCLUSIONS}

This study has examined the differences in location costs between the centralcities and suburbs of urban areas that share Boston's characteristics. The primary conclusion of this paper is that the pursuit of cost minimization by a wide range of manufacturing firms involves very few factors of production and favors suburban location.

The paperextends the logic of earlier work on the transformation of the prototype nineteenth century urban area. For the purposes of the foregoing analysis, it was assumed that this transformation has created a location decision framework where intra-urban transportation cost differentials have been largely voided by the heavy reliance by manufacturing firms on highways and on servicing markets which are distant relative to intraurban travel. The model further assumes that capital is completely mobile over the urban area. Extending the logic of the impact of unrelenting suburbanization of jobs and residences over the last few decades, labor of different skill grades is taken to be available at roughly the same wage at any particular job location. The one exception to this assumption of wage parity is provided by the socalled secondary labor market, which is considered to be, at best, a neutral factor in most manufacturing firm location decisions because potential substitutions for other forms of higher quality-higher wage labor is costly, and upgrading through training, to avoid the need for substitution is also expensive.

It is assumed that, except for some spacialized firms, business services and intermediate products acquired within the urban area are available at prices that do not varyspatially. Building codes and building materials costs are presumed invariant over the relevant region. The substitution possibilities between multilevel and single story structures prove to be limited: first, the costlier multilevel construction per building square foot tends to offset the saving in land use in the real world case of substantial land price differentials between core and suburbia; second, with the existing technology, there appears to be no way multilevel structures can be made as efficient in handling production as single story ones. Therefore, land cost variations a re allowed to play a commanding role in manufacturing location, together with the pricevariation in the provision of government services to the firm. Land price differentials exert this impact at the very time that the cost advantages of the core for most manufacturing firms have been largely eliminated. There remain in the core a number of competing users of land who are forced to bidfor a small amount of vacant land and to undertake demolition of obstructed sites. The resulting land cost differentials, incorporated into hypothetical gross rental differentials between location at model core and suburban industrial parks, prove to have a serious impact on hypothetical net operating profits. As a result, further net losses of central city employment are contained only by the fact thay many core cityfirms have sunk costs associated with earlier decisions to locate in the core and that other firms, specialized manufacturing plants, operate according to production considerations different from those taken as "typical."

This view has a bearing not only on the behavior of individual firms but also for forecasters of economic behavior who place manufacturing location decisions at the heart of exogenous events having a decisive effect on urban employment and residential location patterns. Furthermore, a host of actual and potential public programs a re concerned with solving problems such as the weakening tax base of the central city and the plight of the "disadvantaged" worker through subsidy schemes that would neutralize the attractiveness of suburbia. The feasibility of these approaches can be illuminated by the findings of this study. 
TABLE 1. COMPARATIVE COSTS OF SINGLE STORY AND MULTILEVEL STRUCTURES, PER BUILDING SQUARE FOOT

Single Story Construction Costs $(80,000$ Square feet)

Shell ${ }^{\mathrm{a}} \$ 7.00$

Upgrading

8.00

Total

15.00
Multilevel Construction Costs (4 levels, 80,000 square feet)

$\begin{array}{lr}\text { Shell } & \$ 9.20 \\ \text { including; } & \\ \text { extra floor support } & +1.50 \\ \text { extra wall footage } & 0.75 \\ \text { stairs } & 0.40 \\ \text { roof savings } & \\ & 0.45 \\ \text { Upgrading } & 9.80 \\ \text { including: } & \\ \text { elevator requirements } & \\ & \end{array}$

Total

19.00

Notes:

a. Includes $\$ 1.00$ for "outside work;" $\$ 0.80$ for foundations; $\$ 1.50$ for the steel structure frame; $\$ 0.70$ for the floor slab; $\$ 0.15$ for precast concrete; $\$ 1.50$ for exterior masonry; $\$ 0.60$ for roofing; and $\$ 0.50$ for miscellaneous items.

b. Includes $\$ 0.50$ for heat; $\$ 3.00$ for air conditioning and ventilation; $\$ 0.50$ for acoustical ceiling; $\$ 0.30$ to $\$ 0.75$ for floor tiling; $\$ 1.75$ to $\$ 2.00$ for light; $\$ 1.00$ to $\$ 1.10$ for plumbing; and $\$ 0.40$ for sprinklers.

c. Slab on grade, used for single story floors, costs $\$ 0.50$ to $\$ 0.70$ per building square foot while additional floors can only be constructed for $\$ 2.50$ to $\$ 2.70$. On a per square foot basis, this involves a differential of $\$ 1.50$ in the illustrated case.

d. Exterior walls cost at least $\$ 2.50$ per square foot of wall. A rectangular single story structure containing 80,000 square feet of building space and 20 foot high ceilings generates costs equivalent to $\$ 0.75$ per square foot of building. A rectangular 4 level building requires, on a building square foot basis, an additional expenditure of $\$ 0.75$ for a total of $\$ 1.50$.

e. Based on two sets of stairs.

f. The same amount of space of the multilevel structure can be covered by one-fourth the amount of roofing needed in the single story structure of equivalent size.

g. Following the recommendations of Chester Browne Associates of Boston; it was assumed that the building needed two passenger elevators traveling at 200 feet per minute and four 4-ton freight elevators operating at a minimum speed of 150 feet per minute.

Sources: Nordblam Corporation and Vappi Construction Company, Boston 
TABLE 2. DIFFERENTIAL LAND COMPONENT COSTS PER BUILDING SQUARE FOOT IN FAVOR OF CENTRAL CITY MULTILEVEL STRUCTURES, USING SELECTED CORESUBURBAN LAND PRICE COMPARISONS

\begin{tabular}{|c|c|c|c|}
\hline $\begin{array}{l}\text { 4-1evel struc- } \\
1-1 \mathrm{e}-\text { ture } \mathrm{e}^{\mathrm{a}} \text { central } \\
\text { vel struc- city } \\
\text { ture }{ }^{\mathrm{b}} \text { suburban }\end{array}$ & $\begin{array}{l}\text { Land value of } \\
\$ 4.00 \text { per squ- } \\
\text { are foot }\end{array}$ & $\begin{array}{l}\text { Land value of } \\
\$ 5.00 \text { per squ- } \\
\text { are foot }\end{array}$ & $\begin{array}{l}\text { Land value } \\
\text { of } \$ 7.00 \text { per } \\
\text { square foot }\end{array}$ \\
\hline $\begin{array}{l}\text { Land value of } \\
\$ 1.00 \text { per squ- } \\
\text { are foot }\end{array}$ & $\$ 1.00$ & $\$ 0.50$ & $-\$ 0.25$ \\
\hline $\begin{array}{l}\text { Land value of } \\
\$ 1.25 \text { per squ- } \\
\text { are foot }\end{array}$ & $\$ 1.75$ & $\$ 1.75$ & $\$ 0.25$ \\
\hline $\begin{array}{l}\text { Land value of } \\
\$ 2.00 \text { per squ- } \\
\text { are foot }\end{array}$ & $\$ 2.50$ & $\$ 2.00$ & $\$ 1.00$ \\
\hline
\end{tabular}

a. 50\% ground level floor to land ratio

b. $331 / 3 \%$ building-to-land ratio

TABLE 3. DIFFERENTIAL TOTAL COSTS PER BUILDING SQUARE FOOT IN FAVOR OF SUBURBAN SINGLE STORY STRUCTURES USING SELECTED LAND PRICE COMPARISONS

\begin{tabular}{|l|c|c|c|}
\hline $\begin{array}{l}\text { 4-level struc- } \\
\text { 1-leveI tureal central } \\
\text { structure city } \\
\text { suburban }\end{array}$ & $\begin{array}{l}\text { Land value of } \\
\$ 4.00 \text { per squ- } \\
\text { are foot }\end{array}$ & $\begin{array}{l}\text { Land value of } \\
\$ 5.00 \text { per squ- } \\
\text { are foot }\end{array}$ & $\begin{array}{l}\text { Land value } \\
\text { of } \$ 7.00 \\
\text { per squ- } \\
\text { are foot }\end{array}$ \\
\hline $\begin{array}{l}\text { Land value of } \\
\$ 1.00 \text { per squ- } \\
\text { are foot }\end{array}$ & $\$ 3.00$ & $\$ 3.50$ & $\$ 4.50$ \\
\hline $\begin{array}{l}\text { Land value of } \\
\$ 1.25 \text { per squ- } \\
\text { are foot }\end{array}$ & $\$ 2.25$ & $\$ 2.75$ & $\$ 3.75$ \\
\hline $\begin{array}{l}\text { Land value of } \\
\$ 1.50 \text { per squ- } \\
\text { are foot }\end{array}$ & $\$ 1.50$ & $\$ 2.00$ & $\$ 3.00$ \\
\hline
\end{tabular}
a. $50 \%$ ground-floor to land ratio
b. $331 / 3 \%$ building-to-land ratio 
TABLE 4. DIFFERENTIAL TOTAL COSTS PER BUILDING SQUARE FOOT OF USABLE SPACE ${ }^{\mathrm{a}}$ IN FAVOR OF SUBURBAN SINGLE STORY STRUCTURES

\begin{tabular}{|c|c|c|c|}
\hline 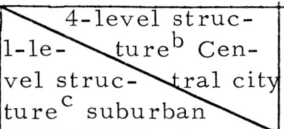 & $\begin{array}{l}\text { Land value of } \\
\$ 4.00 \text { per squ- } \\
\text { are foot }\end{array}$ & $\begin{array}{l}\text { Land value of } \\
\$ 5.00 \text { per squ- } \\
\text { are foot }\end{array}$ & $\begin{array}{l}\text { Land value } \\
\text { of } \$ 7.00 \\
\text { per square } \\
\text { foot }\end{array}$ \\
\hline $\begin{array}{l}\text { Land value of } \\
\$ 1.00 \text { per squ- } \\
\text { are foot }\end{array}$ & $\$ 3.90$ & $\$ 4.55$ & $\$ 5.85$ \\
\hline $\begin{array}{l}\text { Land value of } \\
\$ 1.25 \text { per squ- } \\
\text { are foot }\end{array}$ & $\$ 2.93$ & $\$ 3.58$ & $\$ 4.88$ \\
\hline $\begin{array}{l}\text { Land value of } \\
\$ 1.50 \text { per squ- } \\
\text { are foot }\end{array}$ & $\$ 1.95$ & $\$ 2.60$ & $\$ 3.90$ \\
\hline
\end{tabular}

Note:

a. Single story space yields 1.3 times more usable space pergross building square foot than multilevel space.

b. $50 \%$ ground level floor-to-land ratio

c. $331 / 3 \%$ building-to-1and ratio

TABLE 5. DIFFERENTIAL TOTAL COSTS ${ }^{\mathrm{a}}$ PER BUILDING SQUARE FOOT IN FAVOR OF SUBURBAN SINGLE STORY STRUCTURES USING SELECTED LAND PRICE COMPARISONS

\begin{tabular}{|l|l|c|c|}
\hline $\begin{array}{l}\text { 1-le-1evel struc- } \\
\text { vel } \\
\text { structure } \\
\text { suburban }\end{array}$ & $\begin{array}{l}\text { Land value of } \\
\text { city } \\
\text { trum } \\
\text { are foot }\end{array}$ & $\begin{array}{l}\text { Land value of } \\
\$ 5.00 \text { per squ- } \\
\text { are foot }\end{array}$ & $\begin{array}{l}\text { Land value } \\
\text { of } \$ 7.00 \\
\text { per square } \\
\text { foot }\end{array}$ \\
\hline $\begin{array}{l}\text { Land value of } \\
\$ 1.00 \text { per squ- } \\
\text { are foot }\end{array}$ & $\$ 5.00$ & $\$ 7.00$ & $\$ 11.00$ \\
\hline $\begin{array}{l}\text { Land value of } \\
\$ 1.25 \text { per squ- } \\
\text { are foot }\end{array}$ & $\$ 4.25$ & $\$ 6.25$ & $\$ 10.25$ \\
\hline $\begin{array}{l}\text { Land value of } \\
\$ 1.50 \text { per squ- } \\
\text { are foot }\end{array}$ & $\$ 3.50$ & $\$ 5.50$ & $\$ 9.50$ \\
\hline
\end{tabular}

Note:

a. Differential total costs in this case consist only of differential land component costs per building square foot. Construction costs for single story space are identical at all locations. The differentials need not be translated into "per building square foot of usable space" because the characteristics of single-story structures are the same at all locations.

b. $50 \%$ building-to-land ratio

c. $331 / 3 \%$ building-to-land ratio 


\section{TABLE 6. REMODELING COSTS PER SQUARE FOOT OF SALVAGEABLE BUILDING EXCLUDING ANY ACQUISITION COSTS ${ }^{\mathrm{a}}$}

Shell Modernization ${ }^{\mathrm{b}}$

Shell upgrading to usable manufacturing space ${ }^{c}$

Parking a rea preparations

Obsolete structures: acquisitions ${ }^{d}$ Obsolete structures: demolition ${ }^{\mathrm{e}}$ Paving ${ }^{2}$
$\$ 2.00$

$9.00+$

1.50

0.70

0.25

Notes:

a. A structure which is old yet income producing could yield gross rentals of $\$ 0.50$ to $\$ 1.50$ per square foot. If net rentals on old structures are taken to be roughly 75 percent of gross rentals (assuming no mortgage expenses), and if net rentals are capitalized by a factor of 5, then per square foot of building values could range from $\$ 1.75$ to $\$ 5.65$. A structure with the desirable characteristics listed as necessary for successful remodeling is most likely to sell from prices close to the upper part of that range.

b. Rough estimate of costs of stripping an older building and making modest modifications to the basic shell structure. Information based on interviews with engineers at Anderson-Nichols Company of Boston.

c. The rough cost of upgrading a shell, following Table 1 .

d. Obsolete structure of same size as salvageable structure covers the same amount of land as the latter building. For illustrative purposes, the hypothetical net income capitalized by a factor of 5 is equal to $\$ 30$, yielding a sale value of $\$ 1.50$ per square foot of building square feet.

e. Demolition costs a re assumed to equal $\$ 0.70$ per square foot of building space. Since both buildings are of equal size, this translates into an equivalent $\$ 0.70$ per square foot of the salvageable building.

f. Paving costs equal $\$ 1.00$ per square foot of covered land area. This is equivalent to $\$ 0.25$ per square foot of salvageable building space if that structure has 4 levels with the ground floor completely covering the original land a rea.

Source: Anderson-Nichols Company; Boston Redevelopment Authority. 
TABLE 7. NET RENTALS ${ }^{\mathrm{a}}$ IN FOUR LOCATIONS UNDER A 1:2 BUILDING-TO-LAND RATIO

\begin{tabular}{|c|c|c|c|c|}
\hline & $\begin{array}{l}\text { Suburban Case } \\
\text { I: Land Cost } \\
\text { of } \$ 1 \text { per sq. } \\
\text { ft. }\end{array}$ & $\begin{array}{l}\text { Suburban Case } \\
\text { II: Land Cost } \\
\text { of } \$ 1.25 \text { per } \\
\text { sq. ft. }\end{array}$ & $\begin{array}{l}\text { Core Case I: } \\
\text { Land Cost of } \\
\$ 4 \text { per sq. ft. }\end{array}$ & $\begin{array}{l}\text { Core Case II: } \\
\text { Land Cost of } \$ 7 \\
\text { per sq. ft. }\end{array}$ \\
\hline $\begin{array}{l}\text { Land Charges } \\
\text { per Yearb }\end{array}$ & $\$ 0.21$ & $\$ 0.26$ & $\$ 0.84$ & $\$ 1.47$ \\
\hline $\begin{array}{l}\text { Building Char- } \\
\text { ges per Year }\end{array}$ & $\$ 1.58$ & $\$ 1.58$ & $\$ 1.58$ & $\$ 1.58$ \\
\hline $\begin{array}{l}\text { Developer } \\
\text { Profit }\end{array}$ & $\$ 0.27$ & $\$ 0.28$ & $\$ 0.36$ & $\$ 0.46$ \\
\hline $\begin{array}{l}\text { Net net } \\
\text { Rentals }\end{array}$ & $\$ 2.06$ & $\$ 2.12$ & $\$ 2.78$ & $\$ 3.51$ \\
\hline
\end{tabular}

Notes:

a. Rental charges exclude utilities and taxes.

b. Based on a financing constant of 10.5 percent per year on a 25 year mortgage at 9.5 percent.

c. See note 2; costs of access roads and utility easements a re pro-rated.

d. 15 percent added to the land plus building charges. For "weak" tenants this percentage can rise to 30 , reflecting greater risk. 
TABLE 8. NET RENTALS ${ }^{\mathrm{a}}$ IN FOUR LOCATIONS UNDER A 1:3 PREVAILING BUILDING-TO-LAND

\begin{tabular}{|l|c|c|c|c|}
\hline & $\begin{array}{l}\text { Suburban Case } \\
\text { I: Land Cost } \\
\text { of } \$ 1 \text { per sq. }\end{array}$ & $\begin{array}{l}\text { Suburban Case } \\
\text { II: Land Cost } \\
\text { of } \$ 1.25 \text { per }\end{array}$ & $\begin{array}{l}\text { Core Case I: } \\
\text { Land Cost of } \\
\$ 4 \text { per sq. ft. }\end{array}$ & $\begin{array}{l}\text { Core Case II: } \\
\text { Land Cost of } \$ 7 \\
\text { per sq. ft. }\end{array}$ \\
\hline $\begin{array}{l}\text { Land charges } \\
\text { per yearb }\end{array}$ & $\$ 0.31$ & $\$ 0.39$ & $\$ 1.26$ & $\$ 2.20$ \\
\hline $\begin{array}{l}\text { Building char- } \\
\text { ges per yearc }\end{array}$ & $\$ 1.58$ & $\$ 1.58$ & $\$ 1.58$ & $\$ 1.58$ \\
\hline $\begin{array}{l}\text { Developer } \\
\text { Profit }\end{array}$ & $\$ 0.28$ & $\$ 0.30$ & $\$ 0.42$ & $\$ 0.56$ \\
\hline $\begin{array}{l}\text { Net net } \\
\text { Rentals }\end{array}$ & & $\$ 2.27$ & $\$ 3.27$ & \\
\hline
\end{tabular}

Notes:

a. Rental charges exclude utilities and taxes.

b. Based on a financing constant of 10.5 percent per year on a 25 year mortage at 9.5 percent.

c. See note 2 ; cost of access roads and utility easements are pro-rated.

d. 15 percent added to the land plus building charges. For "weak" tenants this percentage can reach 30 , reflecting greater risk. 
TABLE 9. GROSS AND NET NET RENTALS IN SUBURBAN AND CORE LOCATIONS USING LOCAL BUILDING-TO-LAND RATIOS ${ }^{\mathrm{a}}$

\begin{tabular}{|c|c|c|c|c|}
\hline & $\begin{array}{l}\text { Suburban Case } \\
\text { I: Land Cost } \\
\text { of } \$ 1 \text { per sq. } \\
\text { ft. } 1: 3 \text { ratio }\end{array}$ & $\begin{array}{l}\text { Suburban } \\
\text { Case II: Land } \\
\text { Cost of } \$ 1.25 \\
\text { per sq. ft. } 1: 3 \\
\text { ratio }\end{array}$ & $\begin{array}{l}\text { Core Case I: } \\
\text { Land Cost of } \\
\$ 4 \text { per sq. ft. } \\
1: 2 \text { ratio }\end{array}$ & $\begin{array}{l}\text { Core Case II: } \\
\text { Land Cost of } \$ 7 \\
\text { per sq. ft. } 1: 2 \\
\text { ratio }\end{array}$ \\
\hline $\begin{array}{l}\text { Land charges } \\
\text { per yearb }\end{array}$ & $\$ 0.31$ & $\$ 0.39$ & $\$ 0.84$ & $\$ 1.47$ \\
\hline $\begin{array}{c}\text { Building } \\
\text { charges per } \\
\text { year }\end{array}$ & $\$ 1.58$ & $\$ 1.58$ & $\$ 1.58$ & $\$ 1.58$ \\
\hline $\begin{array}{l}\text { Developer } \\
\text { profit }\end{array}$ & $\$ 0.28$ & $\$ 0.30$ & $\$ 0.36$ & $\$ 0.46$ \\
\hline $\begin{array}{l}\text { Net net } \\
\text { Rentals }\end{array}$ & $\$ 2.17$ & $\$ 2.27$ & $\$ 2.78$ & $\$ 3.51$ \\
\hline $\begin{array}{l}\text { Utility } \\
\text { charges }\end{array}$ & $\$ 0.15$ & $\$ 0.15$ & $\$ 0.15$ & $\$ 0.15$ \\
\hline $\begin{array}{l}\text { Real estate } \\
\text { property tax }\end{array}$ & $\$ 0.72$ & $\$ 0.75$ & $\$ 1.15$ & $\$ 1.45$ \\
\hline Gross rentals & $\$ 3.04$ & $\$ 3.17$ & $\$ 4.08$ & $\$ 5.31$ \\
\hline
\end{tabular}

Notes:

a. The suburban plans a re evaluated at a 1:3 building-to-land ratio; the core plans a re evaluated at a 1:2 building-to-land ratio.

b. Basedon a financing constant of 10.5 percent per year on a 25 year mortgage at 9.5 percent.

c. See note 2 ; costs of access roads and utility easements are pro-rated.

d. 15 percent added to the land plus building charges. For "weak" tenants this percentage can rise to 30 , reflecting greater risks. 
e. Arbitrarily given, without regard for special requirements, especially light-levels. Wate r costs a re negligible; heat charges a re circa 8-10 cents per square foot.

f. 4 percent rate applied to suburbia; 5 percent rate applied to core. 
TABLE 10. PERCENTAGE DIFFERENTIALS IN RENTALS UNDER

CONDITIONS OF TABLE 7,8 AND 9*

USING SUBURBAN RATES AS BASES

Net Net Rental

Differentials

Under a $1: 3$

Building - to-

Land Coverage
Net Net Rental

Differentials

Under a $1: 2$

Building-to-

Land Coverage

Ratio
Net Net Rental

Differentials

Under a $1: 3$

Coverage Ratio

In Suburbia and

a 1:2 Coverage

Ratio in the

Core
Gross Rental

Differentials

Under a 1:3

Coverage

ratio in sub-

urbia and a

1:2 coverage

Ratio in the

Core

Suburban Case I

versus Core

$57 \%$

$35 \%$

$29 \%$

$34 \%$

Suburban Case

versus Core

$70 \%$

$63 \%$

$75 \%$

Suburban Case II

versus Core

$44 \%$

$32 \%$

$23 \%$

$29 \%$

Suburban Case II

versus Core

$91 \%$

$66 \%$

$55 \%$

$68 \%$

*Percentages rounded of 
TABLE 11. SALES DISTRIBUTION BY CATEGORY

\begin{tabular}{|c|c|c|c|c|}
\hline Industry & Electronics & $\begin{array}{c}\text { Camputer } \\
\text { Peripherals }\end{array}$ & $\begin{array}{c}\text { Commericalc } \\
\text { Printing }\end{array}$ & $\begin{array}{r}\text { Metal } \\
\text { Stamping }\end{array}$ \\
\hline Materials & $25 \%$ & $35 \%$ & $36 \%$ & $33 \%$ \\
\hline $\begin{array}{c}\text { Factory } \\
\text { Payroll }\end{array}$ & $35 \%$ & $17 \%$ & $32 \%$ & $25 \%$ \\
\hline $\begin{array}{c}\text { Overheadf } \\
\text { Selling \& } \\
\text { Marketing }\end{array}$ & $12 \%$ & $11 \%$ & $11 \%$ & $10 \%$ \\
\hline $\begin{array}{c}\text { General } \\
\text { Administration }\end{array}$ & $8 \%$ & $13 \%$ & $7 \%$ & $12 \%$ \\
\hline $\begin{array}{c}\text { Net Operating } \\
\text { Profit }\end{array}$ & $10 \%$ & $9 \%$ & $7 \%$ & $8 \%$ \\
\hline
\end{tabular}

\section{Notes:}

a. Information obtained for firms of size range 100-500 employees. Sources include the Electronics Industries of American and area firms.

b. Information obtained for firms of size range 100-500 employees. Sources include the Computer Peripherals Association and area firms.

c. Information obtained for firms of size range 100-500 employees. Sources include the Printing Industries of America and a rea firms.

d. Information obtained for firms of size range 100-500 employees. Sources include the National Metal Stamping Association and area firms.

e. Excludes payrollincluded under selling and marketing and general administration.

f. Includes, among other items, yearly building and machinery equipment charges, as well as property taxes. 
TABLE 12. INTERINDUSTRY COMPARISONS OF FIRM DATA

\begin{tabular}{|c|c|c|c|c|}
\hline & $\begin{array}{l}\text { Electronic } \\
\text { Components }\end{array}$ & $\begin{array}{c}\text { Computer } \\
\text { Periphericals }\end{array}$ & $\begin{array}{c}\text { Commerical } \\
\text { Printing }\end{array}$ & $\begin{array}{c}\text { Metal } \\
\text { Stampings }\end{array}$ \\
\hline $\begin{array}{l}\text { Average Annual } \\
\text { Sales/Worker }\end{array}$ & $\$ 15,000$ & $\$ 24,000$ & $\$ 21,000$ & $\$ 23,000$ \\
\hline $\begin{array}{l}\text { Average Value } \\
\text { Machinery and } \\
\text { Equipment / } \\
\text { Worker }\end{array}$ & $\$ 5,000$ & $\$ 7,500$ & $\$ 7,500$ & $\$ 10,000$ \\
\hline $\begin{array}{l}\text { Average Build- } \\
\text { ing Investment/ } \\
\text { Worker (exclud- } \\
\text { ing land) }\end{array}$ & $\$ 3,000$ & $\$ 4,500$ & $\$ 4,500$ & $\$ 4,500$ \\
\hline $\begin{array}{l}\text { Sq. Ft. /Worker } \\
\text { (building space) }\end{array}$ & 200 sq. ft. & 300 sq. ft. & 400 sq. ft. & 400 sq. ft. \\
\hline $\begin{array}{l}\text { Average Annual } \\
\text { Payroll/Worker }\end{array}$ & $\$ 8,000$ & $\$ 8,100$ & $\$ 9,200$ & $\$ 8,000$ \\
\hline $\begin{array}{l}\text { Factory Emp- } \\
\text { loyees as } \% \text { of } \\
\text { Total }\end{array}$ & $65 \%$ & $60 \%$ & $78 \%$ & $80 \%$ \\
\hline $\begin{array}{l}\text { Average Ann- } \\
\text { ual Pay roll/ } \\
\text { Factory Emp- } \\
\text { loyee }\end{array}$ & $\$ 6,500$ & $\$ 6,800$ & $\$ 8,500$ & $\$ 7,100$ \\
\hline
\end{tabular}

Sources: See Table 11 
TABLE 13. DOLLAR COSTS PER WORKER PER YEAR IN LAND AND NET-GROSS RENTALS

\begin{tabular}{|c|c|c|c|c|}
\hline & $\begin{array}{c}\text { Core Case } \\
\text { I }\end{array}$ & $\begin{array}{l}\text { Core Case } \\
\text { II }\end{array}$ & $\begin{array}{c}\text { Suburban Case } \\
\text { I }\end{array}$ & $\begin{array}{c}\text { Suburban Case } \\
\text { II }\end{array}$ \\
\hline $\begin{array}{l}\text { Land Costs }(200 \\
\text { building sq. ft. } \\
\text { per employee })\end{array}$ & 168 & 297 & 62 & 78 \\
\hline $\begin{array}{l}\text { Net Net Rentals } \\
(200 \text { building } \\
\text { sq. ft. per em- } \\
\text { ployee) }\end{array}$ & 556 & 702 & 434 & 454 \\
\hline $\begin{array}{l}\text { Gross Rentals } \\
\text { ( } 200 \text { building } \\
\text { sq. ft. per } \\
\text { employee) }\end{array}$ & 816 & 1,062 & 608 & 634 \\
\hline $\begin{array}{l}\text { Land Costs } \\
\text { ( } 300 \text { building } \\
\text { sq. ft. per } \\
\text { employee) }\end{array}$ & 252 & 441 & 96 & 117 \\
\hline $\begin{array}{l}\text { Net Net Rentals } \\
\text { ( } 300 \text { building } \\
\text { sq. ft. per } \\
\text { employee) }\end{array}$ & 834 & 1,053 & 651 & 681 \\
\hline $\begin{array}{l}\text { Gross Rentals } \\
\text { ( } 300 \text { building } \\
\text { sq. ft. per } \\
\text { employee) }\end{array}$ & 1,224 & 1,593 & 912 & 951 \\
\hline $\begin{array}{l}\text { Land Cost ( } 400 \\
\text { sq. ft. per em- } \\
\text { employee) }\end{array}$ & 336 & 588 & 124 & 156 \\
\hline $\begin{array}{l}\text { Net Net Rentals } \\
\text { ( } 400 \text { sq. ft. per } \\
\text { employee) }\end{array}$ & 1,112 & 1,404 & 868 & 908 \\
\hline $\begin{array}{l}\text { Gross Rentals } \\
\text { ( } 400 \mathrm{sq} . \mathrm{ft} . \\
\text { per employee) }\end{array}$ & 1,632 & 2,124 & 1,216 & 1,268 \\
\hline
\end{tabular}

Source: Table 9 
TABLE 14. REAL ESTATE TAXES AND NEW CONSTRUCTION RENTALS (NET AND GROSS) IN SUBURBAN AND CORE LOCATIONS AS A PRECENT OF REVENUE

\begin{tabular}{|c|c|c|c|c|}
\hline & $\begin{array}{l}\text { Electronic } \\
\text { Components }\end{array}$ & $\begin{array}{c}\text { Computer } \\
\text { Peripherals }\end{array}$ & $\begin{array}{c}\text { Commeric } \\
\text { Printing }\end{array}$ & $\begin{array}{c}\text { Metal } \\
\text { Stamping }\end{array}$ \\
\hline $\begin{array}{l}\text { Suburban Case } \\
\text { I: Property } \\
\text { Taxes }\end{array}$ & $.9 \%$ & $.8 \%$ & $1 \%$ & $.9 \%$ \\
\hline $\begin{array}{l}\text { Suburban Case } \\
\text { II: Property } \\
\text { Taxes }\end{array}$ & $1 \%$ & $.9 \%$ & $1.1 \%$ & $1 \%$ \\
\hline $\begin{array}{l}\text { Boston Case I: } \\
\text { Property Taxes }\end{array}$ & $1.5 \%$ & 1. $4 \%$ & $1.6 \%$ & 1. $5 \%$ \\
\hline $\begin{array}{l}\text { Boston Case } \\
\text { II: Property } \\
\text { Taxes }\end{array}$ & 1. $9 \%$ & 1. $8 \%$ & $2.1 \%$ & 1. $9 \%$ \\
\hline $\begin{array}{l}\text { Suburban Case } \\
\text { I: a) Net and b) } \\
\text { Gross Rentals }\end{array}$ & $\begin{array}{l}\text { a) } 2.9 \% \\
\text { b) } 4 \%\end{array}$ & $\begin{array}{l}\text { a) } 2.7 \% \\
\text { b) } 3.8 \%\end{array}$ & $\begin{array}{l}\text { a) } 3.1 \% \\
\text { b) } \quad 4.3 \%\end{array}$ & $\begin{array}{l}2.8 \% \\
4 \%\end{array}$ \\
\hline $\begin{array}{l}\text { Suburban Case } \\
\text { II: a) Net and b) } \\
\text { Gross Rentals }\end{array}$ & $\begin{array}{r}\text { a) } \quad 3 \% \\
\text { b) } \quad 4.2 \%\end{array}$ & $\begin{array}{l}\text { a) } 2.8 \% \\
\text { b) } 4 \%\end{array}$ & $\begin{array}{l}\text { a) } 3.2 \% \\
\text { b) } \quad 4.5 \%\end{array}$ & $\begin{array}{l}3 \% \\
4.2 \%\end{array}$ \\
\hline $\begin{array}{l}\text { Core Case I: } \\
\text { a) Net and b) } \\
\text { Gross Rentals }\end{array}$ & $\begin{array}{l}\text { a) } 3.7 \% \\
\text { b) } 5.5 \%\end{array}$ & $\begin{array}{l}\text { a) } 3.5 \% \\
\text { b) } 5.1 \%\end{array}$ & $\begin{array}{l}\text { a) } 3.9 \% \\
\text { b) } 5.8 \%\end{array}$ & $\begin{array}{l}\text { a) } 3.7 \% \\
\text { b) } 5.5 \%\end{array}$ \\
\hline $\begin{array}{l}\text { Core Case II: } \\
\text { a) Net and b) } \\
\text { Gross Rentals }\end{array}$ & $\begin{array}{l}\text { a) } \\
\text { b) } \\
\text { b. } 7.1 \%\end{array}$ & $\begin{array}{l}\text { a) } 4.5 \% \\
\text { b) } 6.7 \%\end{array}$ & $\begin{array}{l}\text { a) } 5.0 \% \\
\text { b) } 7.4 \%\end{array}$ & $\begin{array}{l}\text { a) } \\
\text { b) } 7.7 \% \\
\text { b) } 7 \%\end{array}$ \\
\hline
\end{tabular}

Sources: Table 12 and 13 


\section{FOOTNOTES}

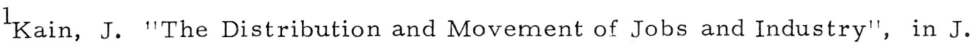
Wilson, ed. The Metropolitan Enigma, Washington, D. C., U.S. Chamber of Commerce, 1967; D. Birch, "The Economic Future of the City and Suburb", New York, Committee for Economic Development Supplementary Paper Number 30, 1970; A.Ganz, "Our Large Cities: New Light on Their Transformation; Elements of a Development Strategy and Prototype Programs", Cambridge, Mass., Massachusetts Institute of Technology Laboratory for Environmental Studies, May, 1971.

2 Data supplied by the Division of Employment Security, Commonwealth of Massachusetts.

${ }^{3}$ Some of the results were summarized in E. D. I. C. , Boston's Industry, Boston, March, 1970.

${ }^{4}$ Those interviewed were asked to associate each answer with an urgency rating of 1 through 4. A rating of 1 indicates a factor of great importance, while a rating of 4 indicates a factor of small import.

${ }^{5}$ Dorfman, R., "Mathematical or 'Linear' Programming: A Non-Mathematical Exposition", American Economic Review, December, 1963, pp. $797-825$.

${ }^{6}$ Summary views of the lite rature can be found in $\mathrm{H}$. Nourse, Regional Economics, New York, McGraw-Hill, 1968; H. Richardson, RegionalEconomics, New York, Praeger, 1969; W. Alonso, "A Reformulation of Classical Location Theory andits Relation to Rent Theory", reprint from Papers of the Regional Science Association, 1967, vol. XIX, in G. Karaska, D. Bramhall, Locational Analysis for Manufacturing, Cambridge, Mass., M.I. T. Press, 1969; R. Fales and L. Moses, Thünes, Weber, and the Spatial Structure of the Nineteenth Century City", Northwestern University, Center for Urban Affairs, manuscript, 1970.

7 Op. cit.

${ }^{8}$ Especially Fales and Moses, op. cit; and L. Moses and H. Williamson, Jr., "The Location of Economic Activity in the Cities", American Economic Review, May 1967, pp. 212, 222.

${ }^{9}$ See, for example, Industry Profiles: 1958-1968, U.S. Department of Commerce, Bureau of Domestic Commerce, Washington, U.S. Government Printing Office, November, 1970. "Machinery and Electrical Equipment Manufacturing". Industry Trends Series 6, U.S. Department of Commerce, Business and Defense Services Administration, Washington, U.S. Government Printing Office, 1969. Table 1-7.

${ }^{10}$ Yeomans, W. "Selections of Production Processes for the Manufacturers' Subsidiaries of U.S. - Based Multinational Corporations", Unpublished dissertation, Harvard University, School of Business, 1968; G. Somers, "Labor Recruitment in a Depressed Rural Area", Monthly Labor Review, October 1958. E. Stanley and R. Morse, Modern Small Industry for Developing Countries, New York, McGraw-Hill, 1965. Further confirmation was found in the industrial recruitment policies of underdeveloped Southern states which were aimed at shaping labor supplies to pre-existing job classifications rather than in trying to encourage incoming firms to adapt technology to the plentiful supply of low skilledlabor. Interviews were conducted with repre- 
sentatives of the Mississippi Argicultural and Industrial Board, the South Carolina State Development Board, and the North Carolina Department of Industry and Conservation.

${ }^{11}$ For a parallel development of this idea with exclusive applications to developing countries, see A. Hirschman, The Strategy of Economic Development, New Haven, Yale University Press, 1958.

12 "Towards a Theory of Intra-Urban Wage Differentials and Their Impact on Travel Patterns", Regional Science Association, 9, 1962, pp. 23-63.

${ }^{13}$ Cities and Housing, Chicago, University of Chicago Press, 1970.

${ }^{14}$ Alonso, W. , Location and Land Use, Cambridge University Press, 1964; D. Denoon and J. Meyer, "Technological Change, Migration Patterns, and Some Issues of Public Policy", Program on Regional and Urban Economics, Discussion Paper \#9, Cambridge, Mass., Harvard University Press, October 1967; R. Muth, 'Economic Change and Rural-Urban Land Conversions. Econometrica, January 1961, pp. 1-23; H. Nourse, op. cit. chapter 5.

${ }^{15}$ Based on information provided by the Boston Redevelopment Authority, the Economic Development and Industrial Commission, representatives of development companies, and representatives of all major realestate agencies dealing in industrial plants and land.

${ }^{16}$ Information based on personal inspection, information provided by the Economic Development and Industrial Commission, and the files of the Boston Redevelopment Authority.

${ }^{17}$ Based on information provided by Anderson-Nichols Co., consulting engineers, and the Duane Co., a demolition concern. The structures are considered obsolete, yielding a hypothetical $\$ 0.30$ per square foot in net income. This was capitalized at half the prevailing rate, to reflect the limited usefulness of the properties inquestion. The building persquare feet value was translated into per square foot of land by assuming ground floor level building coverage of 50 percent and 100 percent. Demolition was calculated at $\$ 0.70$ per square foot of building.

${ }^{18}$ Based on an unpublished summary of B.R.A. projects correct as of June, 1970.

${ }^{19}$ Summary 1965-1975: General Plan for the City of Boston and the Regional Core, Boston, Boston Redevelopment Authority, March 1965, Chapter IV.

${ }^{20}$ Expenditures on office structures ( $\$ 50$ million) were divided by $\$ 25$ to yield building square footage. Using an average building height of 10 stories and a 50 percent ground coverage, the building square feet can be translated into land square feet. The expenditures on all other structures $(\$ 220 \mathrm{mil}-$ lion) were translated into building space by use of a construction cost of $\$ 15$ per square foot. Then, assuming an average building height of 3 levels and 100 percent ground level coverage, a subtotal of 115 acres resulted. Together with the 10 acres for office space, this totals 125 acres per year.

${ }^{21}$ Supplied by the real estate agencies of C.W. Whittier and Brothers, and Ryan and Elliot.

${ }^{22}$ A just published study on New York City confirms the existence of such a trend for manufacturing space in that city. See Planning for Jobs, Supple- 
ment to Plan for New York City, New York, New York City Planning Commission, $\overline{\operatorname{Mar} c h} \overline{1} 971$, p. 9 .

${ }^{23}$ Data obtained from A. Ganz, T. Freeman, Population and Income of the City of Boston, Recent Evolution and Future Perspectives, Boston, Boston Redevelopment Authority, June, 1970; and 1970 Census of Housing - Advance Report, Massachusetts, U.S. Department of Commerce, Bureau of Census, U.S. Government Printing Office, February, 1971.

${ }^{24}$ Based on conversations with renewal administrators of the largest redevelopment sites in Boston, Washington Park, and South End.

${ }^{25}$ Ganz, "Intergovernmental Fiscal Disparities and the Socio-Economic Dvelopment of the Boston Metropolitan Area", Study prepared for the U.S. Advisory Commission on Intergovernmental Relations, November, 1967, Table 17, p. 46; updated by information provided by the Mayor's office, Bos ton, and the State Tax Commission.

26 "1969 Tax Rates, Actual and Full Value", Massachusetts Taxpayers Foundation, October, 1969; "The Tax Situation in Massachusetts Cities and Towns", Boston Globe, September 6, 1970.

27"Assessment - Sales Ratios Under the Boston Property Tax", National Tax Journal, March, 1965, vol. XXIII, No. 1, updated in an unpublished study.

${ }^{28}$ Sources within the State Tax Commission and the Boston Redevelopment Authority.

29"Metropolitan Employment and Population Distribution and the Conditions of the Urban Poor", in J. Crecine, ed., Financing the Metropolis, Beve rly Hills, Sage, 1970.

${ }^{30}$ Wages in the Metropolis, Cambridge, Massachusetts, Harvard University Press, 1960.

${ }^{31}$ Workers and Wages in an Urban Labor Market, Chicago, University of Chicago Press, 1970 .

32 The concept of the typical firm, and the data used to define it, is discussed in Part V.

${ }^{33}$ This corresponds roughly with the average payroll/employee found to prevail in the types of industries considered in this study. See Table 12 .

${ }^{34}$ Internal Labor Markets and Manpower Analysis, manuscript, 1970.

${ }^{35}$ Kinnard, W., Industrial Real Estate, Washington, Society of Industrial Realtors of the National Association of Real Estate Boards, 1967, p.362363.

${ }^{36}$ In fact a study of prototype structures just completed by Weiner, Gran, Associates of New York concluded that two-level structures would cost $12 \%$ more, on a per square foot basis, than a 6-level manufacturing structure. Information based on unpublished research sponsored by the Economic Development Section, New York Planning Commission.

37 Following the logic developed in Part V, land and construction costs per building square foot at all locations could be reduced to a constant annual charge formally equivalent to a mortgage constant. The constant chosen and justified in Part $\mathrm{V}$ is 10.5 percent of total costs perannum. The differential 
advantage of suburbia in Tables 4 and 5 could then be rescaled. Next, the annual property taxes on the illustrative structures could be computed and two additional sets of calculations drawn up. One, to accompany Table 4, would show the property taxdifferential in favor of suburbia when multilevel structures are allowed and the other, to accompany Table 5, would show that differential when multilevel structures are barred in the central city. Finally, the comprehensive annual cost differential in favor of suburbia when multilevel buildings are allowed can be compared to the differential where the latter are excluded. For the sake of economy, the various calculations have been omitted except for the discussion in Part V. It can be shown, however, that in all cases the absolute size of suburbia's advantage is increased when property taxes are considered. That increase is greater when multilevel structures are excluded. Yet even with the addition of property taxes, the percentage decrease in suburbia's advantage when multilevel structures are permitted over the case where they are not, does not differ from the results reached when Tables 4 and 5 were compared.

${ }^{38}$ Lund, M., A. Whitfield, and M. Flaks, "Master Plan to Rebuild Ghettos", Modern Manufacturing, February, 1969, reprint.

${ }^{39}$ Mayor's Committee for Economic and Cultural Development of Chicago, Mid-Chicago Economic Development Study, vol. 1, February, 1966, p. 60.

${ }^{40}$ William A. Gould, Associates, Feasibility and Design of a Prototype

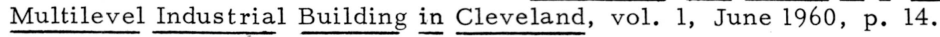

41

${ }^{41}$ Use was made of staff studies made by Cabot, Cabot, and Forkes, real estate developers.

42 Based on information supplied by the Boston Redevelopment Authority and Linnell and Cox, real estate developers.

${ }^{43}$ Based on information provided by sources at State Street Bank of Boston, Cabot, Cabot, and Forkes, and Ryan and Elliot, Co., real estate developers.

${ }^{44}$ See footnote 42.

${ }^{45}$ Research Department, Massachusetts Department of Commerce and Development.

${ }^{46}$ Thus, for example, no attempt was made to measure the effects of scale on the relevant components of scales. 